\title{
Estimativa de perdas de arrecadação de ICMS promovida pela lei Kandir no Corede produção - RS: uma análise sobre as exportações de soja, de 1997 a 2014
}

\author{
Vanessa Soccoloski* \\ Marco Antonio Montoya**
}

\begin{abstract}
Resumo
O Brasil e o Rio Grande do Sul ocupam lugar de destaque na produção de grãos e nas exportações do agronegócio, sendo os principais produtos exportados os do complexo-soja, sobretudo o grão. Possivelmente, a Lei Kandir, que isenta a tributação de ICMS sobre as operações e produções destinadas à exportação (produtos primários, produtos semielaborados ou serviços) exerceu influência direta nesse processo. Buscando mensurar as perdas de arrecadação de ICMS causadas pela aplicação dessa lei, o objetivo desse estudo é evidenciar a participação do Corede Produção nas exportações de soja do Estado, entre os anos de 1997 e 2014. O método adotado para a coleta se deu a partir de dados secundários sobre área plantada, produção, volume e valor de exportação, que foram submetidos à análise descritiva das variáveis vinculadas à exportação, permitindo quantificar os efeitos da lei no estado e no Corede. Os principais resultados obtidos apontam que 16,09\% das perdas líquidas do estado, de 1997 a 2014, se referem à exportação de soja do Corede e as perdas municipais superam os $\mathrm{R} \$ 108$ milhões, demonstrando a sua fundamental participação nos resultados estaduais.
\end{abstract}

Palavras-chave: Soja. Exportações. Lei Kandir. ICMS.

* Graduada em Ciências Econômicas, Administrativas e Contábeis pela Universidade de Passo Fundo (UPF).E-mail: vanessasoccoloski.vs@gmail.com

** Doutor em Economia Aplicada pela Escola Superior de Agricultura Luiz de Queiroz (Esalq/USP). Professor titular da Universidade de Passo Fundo. E-mail: montoya@upf.br

http://dx.doi.org/10.5335/rtee.v24i50.8958

Submissão: 02/08/2016. Aceite: 03/10/2017. 


\section{Introdução}

O Brasil ocupa lugar de destaque na produção e na exportação de produtos agropecuários, devido às condições climáticas favoráveis, alta tecnologia utilizada pelo produtor, boas políticas públicas e de abastecimento, dentre outras. As estimativas de produção para a safra $2015 / 16$ apontavam um crescimento de $2,1 \% \mathrm{em}$ relação à safra 2014/15, estimando um aumento de 4,9 a 6,6 milhões de toneladas de soja para o período (CONAB, 2015). Entre 2014 e 2015 o Brasil exportou 54,50 milhões de toneladas de soja e as estimativas de aumento nas exportações do grão são de 1,95 milhões de toneladas para o próximo ano (CONAB, 2015, p. 123).

De acordo com as informações do sistema Agrostat do Ministério da Agricultura, Pecuária e Abastecimento (Mapa), 65\% das exportações do estado do Rio Grande do Sul, em 2014, provém do agronegócio e os principais complexos exportados são os da soja $(44,1 \%)$, das carnes $(18,41 \%)$, do fumo $(15,6 \%)$ e de couros $(7,3 \%)$ (BRASIL, 2015).

Possivelmente, a criação da lei complementar $\mathrm{n}^{\mathrm{o}}$ 87, de 13 de setembro de 1996, mais conhecida como Lei Kandir, que em seu artigo $3^{\circ}$, inciso II, decreta a não incidência do Imposto sobre Operações relativas à Circulação de Mercadorias e sobre Prestação de Serviços de Transporte Interestadual e Intermunicipal e de Comunicações (ICMS) nas operações e produções destinadas à exportação, desde produtos primários a produtos semielaborados, ou serviços, influenciou diretamente nesse cenário promissor do setor (BRASIL, 2011).

O ICMS é um tributo de responsabilidade do governo estadual, o qual tem maior participação no total das receitas tributárias, representando 20,93\% de tudo o que foi arrecadado no Brasil em 2013 e é responsável por 7,52\% do Produto Interno Bruto (PIB) no mesmo período (BRASIL, 2014).

A garantia de isenção de tributação de ICMS proposta pela Lei Kandir sobre as exportações, possibilitou que os produtos brasileiros se posicionassem de maneira mais competitiva no mercado internacional. Porém a arrecadação de ICMS sofreu grandes reduções, pois, apesar da lei garantir um sistema compensatório denominado "Seguro Receita", esse não é cumprido rigorosamente pelo governo federal (SANTOS; MARTA, 2011).

Frente a esse panorama, essa pesquisa questiona qual é o volume de perdas de arrecadação devido à aplicação dessa lei sobre as exportações de soja nos municípios que compõem o Conselho Regional de Desenvolvimento da região da Produção (Corede Produção) no estado do Rio Grande do Sul? 


\section{Referencial teórico}

\subsection{Soja: importância para o agronegócio brasileiro e sul-rio-grandense}

O cultivo comercial de soja no Brasil iniciou em 1914, no estado do Rio Grande do Sul. Foi na década de 1940 que ela foi considerada fator importante para a economia brasileira, mas ganhou representatividade no agronegócio nos anos 1970, quando os produtores de trigo passaram a utilizar as mesmas terras, máquinas e mão-de-obra, para o cultivo da soja, já que ocorriam em estações diferentes (DALL'AGNOL, 2016).

Na década de 1980 o Rio Grande do Sul perdeu significativamente seu espaço na participação na produção brasileira de soja, reflexo da migração dos produtores para outros estados, provocada pela alta dos preços da terra no estado (DALL'AGNOL, 2016). A estagnação no crescimento da área de cultivo, produção e rendimento no estado teve como principais fatores, a estiagem nos anos de 1978 e 1979, a insatisfação dos produtores em relação à política de confisco cambial promovida pelo governo federal; a degradação do solo ocasionada pelo cultivo intensivo; e a retração do mercado internacional (TRENNEPOHL; PAIVA, 2011).

A expansão do seu cultivo influenciou a modernização e a expansão das fronteiras agrícolas no Brasil, além de outras contribuições. Trennepohl e Paiva (2011) afirmam ainda que "além da produção agrícola, desenvolveu-se uma ampla estrutura industrial, comercial e de serviços," denominada complexo-soja, que tem como componentes toda a cadeia produtiva do grão, óleo e farelo de soja.

Apesar da posição de destaque do Brasil em relação à produção de soja, o fator competitividade apresenta alguns problemas, Lazzaroto e Hiracury (2009) salientam que a competitividade da produção nacional de soja baseia-se em vantagens comparativas, muito mais do que em vantagens competitivas, pois fatores como: altos custos de frete, elevadas despesas portuárias, deficiências na infraestrutura de armazenamento bem como as altas cargas tributárias e taxas de juros, aliadas ao nível elevado de endividamento dos produtores e deficiências de gestão rural contribuem para o que eles denominam "estrangulamento" da competitividade desse complexo.

Dados obtidos na safra 2014/2015 apontam que os maiores produtores de soja brasileiros foram Mato Grosso, Paraná e o Rio Grande do Sul, (CONAB, apud EMBRAPA, 2015).Quanto às exportações, o grão de soja sempre se destacou por 
apresentar custos inferiores no seu processo produtivo, e até a década de 1990, a comercialização interna do grão foi estimulada por meio de políticas públicas, visando suprir as necessidades da pecuária, que apresentava um crescimento expressivo no período (TRENNEPOHL; PAIVA, 2011).

\subsection{O cenário econômico brasileiro a partir de 1990}

Na década de 1990, a abertura econômica brasileira visava alterar o estilo de desenvolvimento protecionista da industrialização, estimulando as importações. Paralelo a essa abertura o país enfrentava um descontrole inflacionário, apesar das inúmeras tentativas de estabilização (CAMARGOS, 2002, p.2).

O Plano Real, implantado em 1994, como medida de recuperação do controle inflacionário, aliado à política cambial adotada pelo governo e a demais fatores da economia interna e externa, alavancou a valorização da moeda, desestimulando as exportações brasileiras, o produto nacional foi encarecido no comércio exterior, e a atratividade promovida pelos produtos estrangeiros elevaram as importações, gerando déficits comercias (FLAVIANO; MEDEIROS; CARVALHO, 2004).

Segundo Camargos (2002, p. 3) entre os anos de 1988 e 1997, as exportações brasileiras aumentaram, em média, 4,6\% ao ano, no entanto as importações quadriplicaram, apresentando um crescimento médio de $15,4 \%$ ao ano, resultando em saldos negativos na balança comercial.

A evolução da balança comercial no período de 1989 a 2014, representada no Gráfico 1, aponta que de 1995 a 2000 os saldos foram déficits sucessivos, resultados influenciados pela "forte instabilidade conjuntural, tanto doméstica quanto internacional, marcada pelas crises econômicas na Ásia, Rússia e o próprio Brasil" no período, dificultando o financiamento do comércio exterior no país (FLAVIANO; MEDEIROS; CARVALHO, 2004). 
Gráfico 1 - Evolução da balança comercial brasileira e da balança comercial do agronegócio de 1989 a 2014

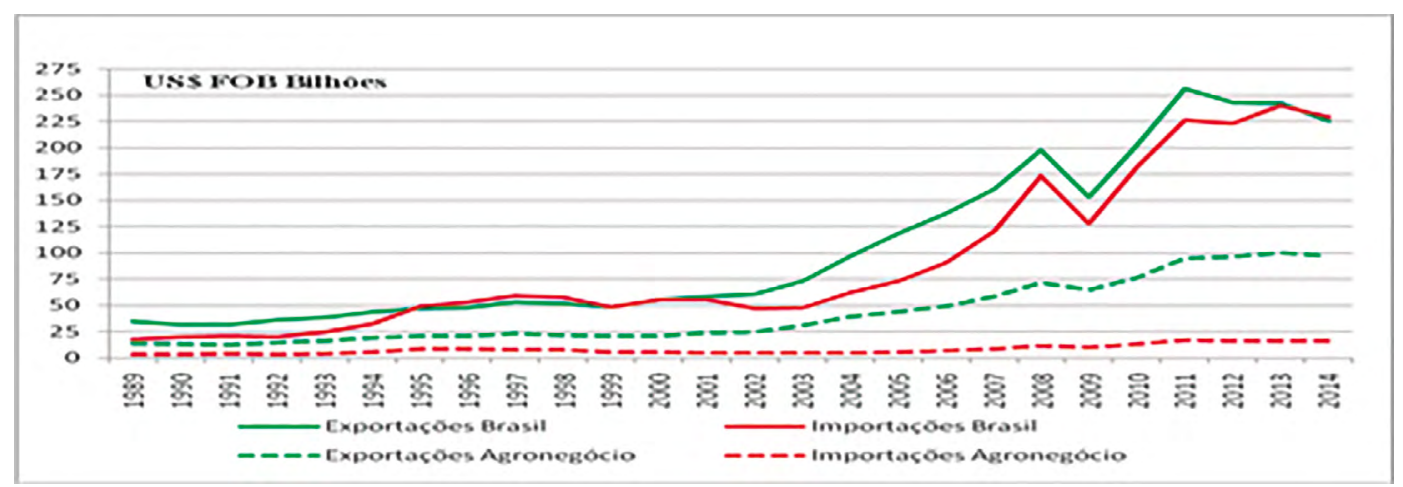

Fonte: elaborado pela autora com base em Agrostat (2016).

A sua recuperação da balança comercial se deu no ano de 2001, crescendo progressivamente até 2006, resultado do crescimento das exportações proporcionalmente maior que o das importações. Tal contexto foi promovido pela entrada da China na Organização Mundial do Comércio (OMC) nesse ano e o seu rápido desenvolvimento, somados ao crescimento do comércio mundial e à valorização do dólar (BRUM apud BENDER FILHO, 2015).

No período de 2007 a 2013, os saldos comerciais sofreram quedas gradativas, mas mantiveram seus resultados positivos. Porém, no ano de 2014, apresentaram um déficit de U\$S 4 bilhões. Os principais fatores que influenciaram essa queda foram o aumento nas importações de petróleo, alto volume de exportação de commodites, que possuem um menor valor agregado e a redução do crescimento na China, dentre outros (FECOMERCIO, 2016).

Diferentemente das oscilações nos resultados econômicos totais, a balança comercial do agronegócio apresentou crescimento constante ao longo da série analisada. Segundo dados da Agrostat (2015), as exportações do setor aumentaram em torno de $8 \%$ ao ano, enquanto que as importações cresceram apenas $3 \%$ ao ano no mesmo período. Portanto as exportações exerceram papel fundamental na busca pelo equilíbrio da balança comercial brasileira, sendo que em 1996 foi responsável por 44,29\% do que foi exportado pelo país e, mesmo tendo apresentado algumas reduções ao longo do período analisado, atingiu a participação de 35,90\%, em 2006.

Dentre os produtos comercializados pelo setor, o complexo-soja é o principal exportador, seguido do complexo de carnes e o complexo sucroalcooleiro, segundo dados do Instituto de Pesquisa Econômica Aplicada (IPEA) (2014). 
Apesar da expressiva participação do agronegócio nas exportações brasileiras, ainda assim o seu saldo comercial apresentava um déficit de 5,6 bilhões de dólares no ano de 1996, e nesse contexto econômico surgiu a Lei Kandir, buscando aumentar à representatividade do Brasil na economia mundial e regular a balança comercial.

\subsection{Lei Kandir: um breve histórico}

Como medida para regular o desequilíbrio na economia brasileira a partir do Plano Real, foi criada Lei Kandir. Essa lei se caracteriza pela mudança na forma de tributação estadual, o ICMS, desonerando completamente as operações de exportação de matérias-primas e alguns produtos industrializados e semielaborados, aumentando a competitividade brasileira no mercado externo (SANTOS; MARTA, 2011).

Sendo assim, as unidades da federação tiveram a sua arrecadação de ICMS comprometida e a fim de amenizar as perdas com a tributação, o governo federal instituiu uma forma de compensação por meio de transferências de recurso para estados e municípios, denominado seguro receita, um mecanismo utilizado para garantir a manutenção do nível médio de receita proveniente desse imposto. $\mathrm{Ou}$ seja, caso a arrecadação estadual fosse inferior à base calculada pelo governo federal que ressarciria os estados, mas as regras de compensação foram alteradas ao longo do tempo (LEITÃO; IRFFI; LINHARES, 2012).

Esse modelo com compensação é motivo de inúmeras divergências entre os estados e a União, sendo que a grande maioria deles o considera ineficiente, e "diante das constantes modificações na legislação, o fato é que o volume de recursos colocados à disposição de estados e municípios como compensação tem determinado o embate político" (SANTOS; MARTA, 2011).

No estado do Rio Grande do Sul, segundo dados da Secretaria da Fazenda - (SEFAZ, 2015), omaior percentual de repasses da União em relação ao cálculo de perdas de ICMS promovida pela lei, se deu no ano de 1998 (80\%) e o Gráfico 2 apresenta a evolução da participação desse ressarcimento de 1996 a 2014. 
Gráfico 2 - LC 87/96 (RS): Participação do ressarcimento da União nas perdas de ICMS com a desoneração das exportações de primários e semi-elaborados + créditos do ativo fixo

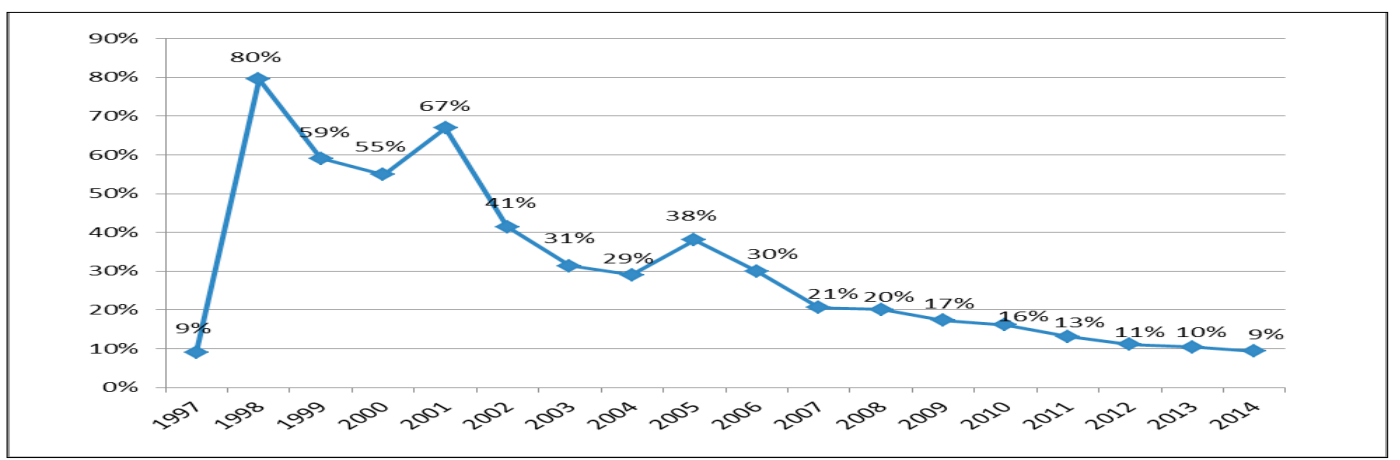

Fonte: Sefaz (2015).

A partir dessas informações levantadas pela Sefaz, é compreensível o descontentamento por parte do estado em relação às falhas no sistema de compensação proposto, corroborando a afirmação de Ferraz (apud SANTOS; MARTA, 2011) de que a Lei Kandir provocou grandes perdas na arrecadação de ICMS, principalmente nos estados que tem a exportação como principal fator econômico.

\subsection{Características da lei do ICMS}

A lei de Imposto sobre Operações relativas à Circulação de Mercadorias e sobre Prestação de Serviços de Transporte Interestadual e Intermunicipal e de Comunicações (ICMS) trata-se de um tributo estadual e, no Rio Grande do Sul, a sua regulamentação se dá pelo Decreto no 37.699 de 26 de agosto de 1997 (RIO GRANDE DO SUL, 1997).

O repasse dos valores arrecadados do ICMS pelo estado é estabelecido pela Constituição federal de 1988 que, em seu artigo 158, inciso IV, dispõe que "vinte e cinco por cento do produto da arrecadação do imposto do Estado sobre operações relativas à circulação de mercadorias e sobre prestações de serviços de transporte interestadual e intermunicipal e de comunicação" pertencem aos municípios.

Antes da aprovação da Lei Kandir, a tributação incidente sobre a exportação de soja e derivados possuía uma diferenciação, sendo que o Brasil taxava a exportação de soja em grão em $13 \%$, farelo $11 \%$ e óleo $8,5 \%$, de modo a incentivar o processamento interno do grão (SCHNEPF; DOHLMAN; BOLLING, apud BENDER FILHO, 2010). 
Com a criação da lei Kandir, ao invés de o governo federal incentivar que a matéria-prima fosse processada internamente e vendida com maior valor agregado, preferiu que essa saísse do país para receber esse tratamento e quem sofreu diretamente com essa alteração foram os estados, que tiveram sua arrecadação comprometida, atingindo, consequentemente, os municípios que não receberam os repasses, devido à não arrecadação do tributo.

\subsection{O Conselho Regional de Desenvolvimento da Produção - RS}

Os Coredes foram estruturados no ano de 1991, mas só em 1994 é que foram instituídos legalmente, por meio da Lei Estadual no 10.283/1994 e regulamentos pelo Decreto no 35.764/1994, sendo eles "fóruns regionais de discussão sobre estratégias, políticas e ações que visam ao desenvolvimento regional, constituídos como pessoas jurídicas de direito privado, organizados sob a forma de associações sem fins lucrativos", ao todo são 28 Coredes (BÜTTENBENDER; SIEDENBERG; ALLEBRANDT, 2011).

O Corede Produção foi inicialmente constituído por 23 municípios: Almirante Tamandaré, Camargo, Carazinho, Casca, Chapada, Ciríaco, Coqueiros do Sul, Coxilha, David Canabarro, Ernestina, Gentil, Marau, Mato Castelhano, Muliterno, Nova Alvorada, Nova Boa Vista, Passo Fundo, Pontão, Santo Antônio do Palma, Santo Antônio do Planalto, São Domingos do Sul, Vanini e Vila Maria (FINAMORE, 2010, p. 20). Porém, 2006 uma nova divisão de regiões criou um novo Corede denominado Rio da Várzea e os municípios de Chapada e Nova Boa Vista deixaram de pertencer ao Corede Produção (BERTÊ et al., 2016, p. 737).

Atualmente, a população do Corede Produção corresponde a 3,16\% do total estadual. Em 2010, eram 338.049 habitantes. Sua estrutura agropecuária tem uma estreita relação com o setor industrial, principalmente nos segmentos de máquinas e equipamentos. A sua base produtiva baseia-se na criação de aves, bovinos, na produção de grãos e no grande potencial produtivo agrícola regional em constante crescimento. Em 2012, o Produto Interno Bruto (PIB) per capita era de R $\$$ $31.776,00$, em torno 23,\% a mais que a média estadual, tendo como principais contribuintes os municípios de Passo Fundo, Carazinho e Marau (BERTÊ et al., 2016).

Os Coredes são fundamentais para um desenvolvimento equilibrado entre as regiões do estado, o aprofundamento sobre informações da sua atuação, bem como da sua participação na produção e nas exportações de soja no estado são de

Teoria e Evidência Econômica - a. 24, n. 50, p. 51-88, jan./jun. 2018 
extrema importância, tendo em vista que o setor agropecuário tem forte influência no desenvolvimento econômico regional.

\section{Materiais e métodos}

Esta pesquisa foi caracterizada como um estudo descritivo, com uma abordagem quantitativa e um procedimento técnico documental, com base lógica de investigação hipotético-dedutiva, considerando que o objetivo do presente estudo é caracterizar a evolução da produção e exportação de soja no Brasil, no Estado do Rio Grande do Sul e no Corede Produção de 1996 a 2014, estimando o volume de desoneração fiscal no Corede Produção, proveniente da implantação da Lei Kandir.

A coleta se deu a partir de dados secundários disponibilizados de maneira on-line. O período estabelecido para a caracterização da produção e a exportação de soja no Brasil e no Rio Grande do Sul foi do ano de 1996, ano da criação da Lei Kandir, até o ano de 2014, pois a disponibilização por parte do governo federal, das informações relativas aos repasses da referida lei correspondem a essa data.

Já para o Corede Produção estabeleceu-se o período de 1997 a 2014, pois a disponibilização dos dados da exportação por municípios se deu a partir dessas datas, a base para construção da série é a sua estrutura de 2015, composta pelos municípios: Almirante Tamandaré, Camargo, Carazinho, Casca, Ciríaco, Coqueiros do Sul, Coxilha, David Canabarro, Ernestina, Gentil, Marau, Mato Castelhano, Muliterno, Nova Alvorada, Passo Fundo, Pontão, Santo Antônio do Palma, Santo Antônio do Planalto, São Domingos do Sul,Vanini e Vila Maria, com isso, se manteve uma homogeneização.

As informações de área plantada (hectare) e produção de soja (tonelada) foram obtidas no site de pesquisa do Sistema de Recuperação Automática (Sidra), vinculado ao Instituto Brasileiro de Geografia e Estatística (IBGE).

As informações sobre o volume (tonelada) e os valores monetários de exportação foram obtidos no site de pesquisa do Sistema de Análise das Informações de Comércio Exterior - Alice Web, pertencente à Secretaria de Comércio Exterior (Secex), vinculada ao Ministério do Desenvolvimento, Indústria e Comercio Exterior (MDIC), sendo que as informações de valores monetários de exportação de soja em grão ${ }^{2}$ foram obtidas em valores expressos na moeda americana US\$ $\mathrm{FOB}^{3}$,e convertidas para a moeda nacional corrente, através de médias anuais do câmbio disponibilizadas pelo Banco Central (Bacen), é importante ressaltar que na pesquisa por municípios na construção de dados do Corede, nos anos de 1999, 2000 e 2001, 
não foram disponibilizados os volumes e valores de exportação, logo, foi elaborada uma estimativa para esses anos pela média móvel de 1997 a 2002 em todas as séries apresentadas no decorrer da apresentação e da análise dos resultados.

Para a elaboração das estimativas de perdas de arrecadação de ICMS no Corede sobre as exportações de soja, considerou-se o percentual de tributação (13\%), conforme aplicação anterior a implantação da Lei Kandir; o percentual de repasse do seguro receita, por ano, foi obtido por meio de um estudo realizado pela Secretaria da Fazenda do estado do Rio Grande do Sul (Sefaz/RS). Já para a elaboração das estimativas de perdas de repasse do ICMS do Estado aos municípios, considerou-se o percentual de 25\%, conforme estabelecido pela Constituição Federal de 1988, e para obtenção dos valores acumulados pertencentes a cada município do Corede, estabeleceu-se como base a sua participação na produção de soja no período analisado.

O método adotado para a análise de resultados é descritivo, em relação às variáveis vinculadas às exportações, as interpretações dos dados apresentados, discorreram basicamente do cálculo percentual de participação relativa das variáveis apresentadas, além do cálculo das taxas de crescimento anuais, com o objetivo de estabelecer as dinâmicas do setor em diferentes períodos.

\section{Apresentação e discussão dos resultados}

\subsection{Produção e exportação de soja no Brasil: 1996-2014}

Entre os anos de 1996 e 2014 o complexo-soja foi responsável, em média, por $23 \%$ das exportações totais do setor, apresentando um crescimento anual de $16 \%$. Já, nas importações, o crescimento ficou em torno 3\% ao ano, tendo como resultados comerciais, sucessivos superávits (Gráfico 3). 
Gráfico 3 - Evolução da participação do complexo soja na Balança Comercial do Agronegócio no Brasil de 1996 a 2014

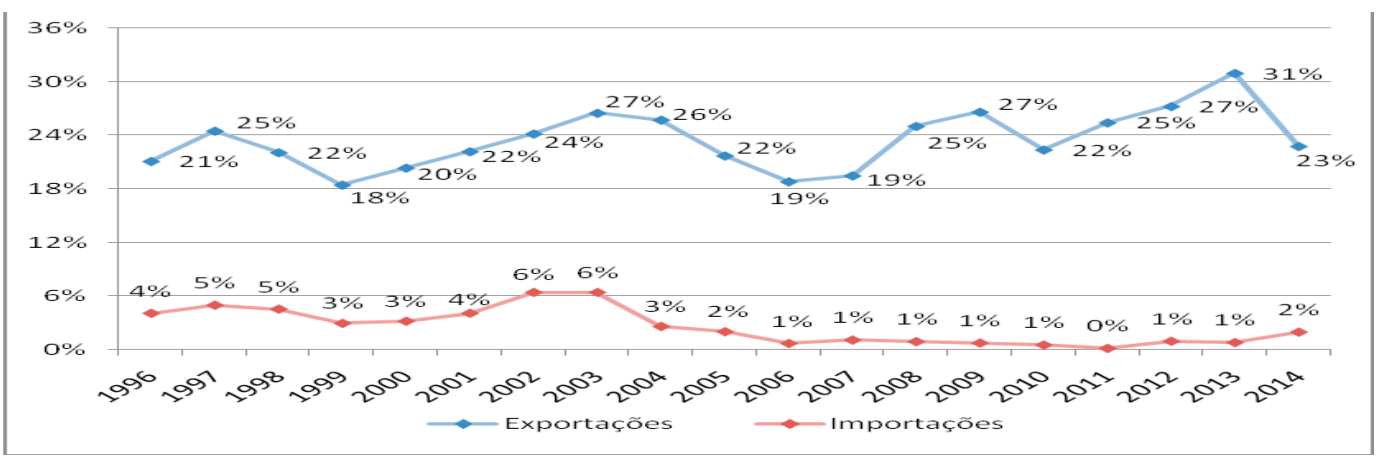

Nota: valores convertidos para a moeda nacional corrente, taxa de câmbio: dólar dos Estados Unidos da América, obtida através de elaboração de média para cada ano pesquisado. Dados disponíveis nos anexos: Tabela 1

Fonte: elaborado pelos autores com base em Agrostat (2016) e Fiergs (2016).

Os incentivos tributários promovidos pelo governo federal em 1996 impulsionaram a exportação da soja em grão, sendo esse o principal componente exportado do complexo e a sua participação e importância no comércio internacional está representada no Gráfico 4, sendo que no ano de 1996 a soja in natura representava apenas $23 \%$ do total exportado do complexo, saltando para $43 \%$ no ano seguinte, e a partir de 1997 a sua participação aumentou em torno de $3 \%$ ao ano, chegando a $74 \%$ em 2014.

Quanto à evolução da quantidade produzida no território brasileiro em 1996 o Brasil produziu em torno de 23 milhões de toneladas de soja e no decorrer do período pesquisado evoluiu positivamente, superando os 86 milhões de toneladas produzidas no país no ano de 2014, apresentando um crescimento anual de $7 \%$, conforme representado no Gráfico 5. 
Gráfico 4 - Participação da soja em grão nas exportações brasileiras do complexo-soja de 1996 a 2014

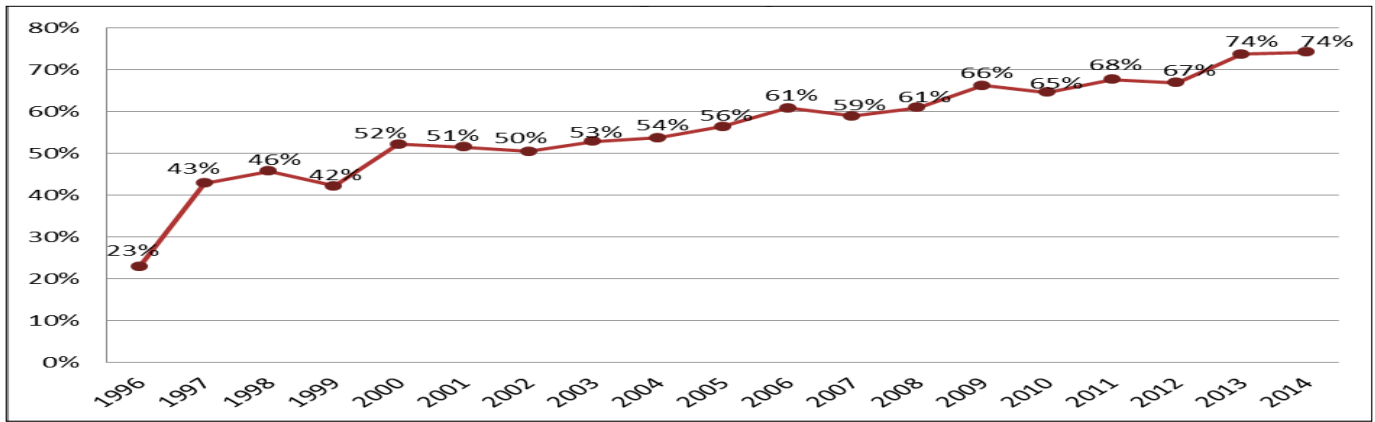

Nota: valores convertidos para a moeda nacional corrente, taxa de câmbio: dólar dos Estados Unidos da América, obtida através de elaboração de média para cada ano pesquisado. Dados disponíveis nos anexos: Tabela 2

Fonte: elaborado: pelos autores com base em Fiergs (2016).

Gráfico 5 - Evolução da produção de soja no Brasil de 1996 a 2014

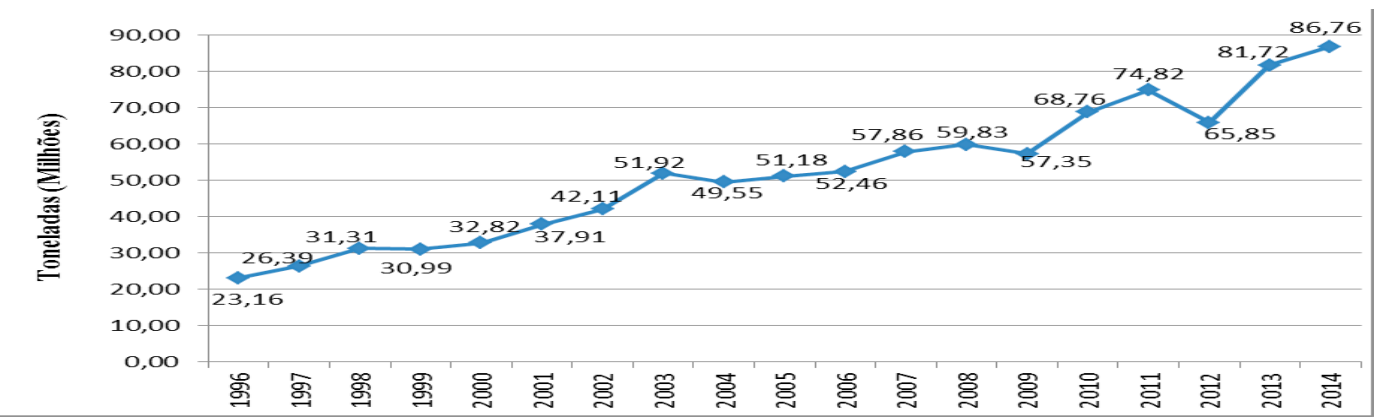

Nota: informações da exportação de soja em grão a partir da cesta de produtos: soja para semeadura; outros grãos de soja mesmo triturados; soja mesmo triturada, para semeadura; soja mesmo triturada, exceto para semeadura Valores convertidos para a moeda nacional corrente, taxa de câmbio: dólar dos Estados Unidos da América, obtida através de elaboração de média para cada ano pesquisado. Dados disponíveis nos anexos: Tabela 3

Fonte: elaborado pelos autores com base em Aliceweb (2016); IBGE (2016); Bacen (2016).

Em 1996 foi exportado 15,75\% de tudo o que foi produzido no país, saltando para $29,51 \%$ no ano de 1997 . No mesmo período, a produção do grão aumentou apenas $14 \%$ de um ano para o outro, mas o volume que foi destinado ao exterior foi $87 \%$ superior, sugerindo que a Lei Kandir foi protagonista nesse processo. Ao longo da série o crescimento foi de $6,83 \%$ ao ano, chegando a 53,81\% em 2014, dados representados no Gráfico 6. 
Quando analisados os dados de exportação do grão, em valores monetários, as variações percentuais e o crescimento são superiores e essa diferença está associada às variações na taxa de câmbio no período. Em 1996 foram exportados 1,022 bilhões reais e em 2014 os valores chegaram a $\mathrm{R} \$ 54,797$ bilhões, apresentando um crescimento de $22 \%$ ao ano, o aumento mais expressivo (159\%) se deu entre os anos de 1996 e 1997(vide anexo: Tabela 3).

Gráfico 6 - Participação das exportações na produção de soja em grão de 1996 a 2014

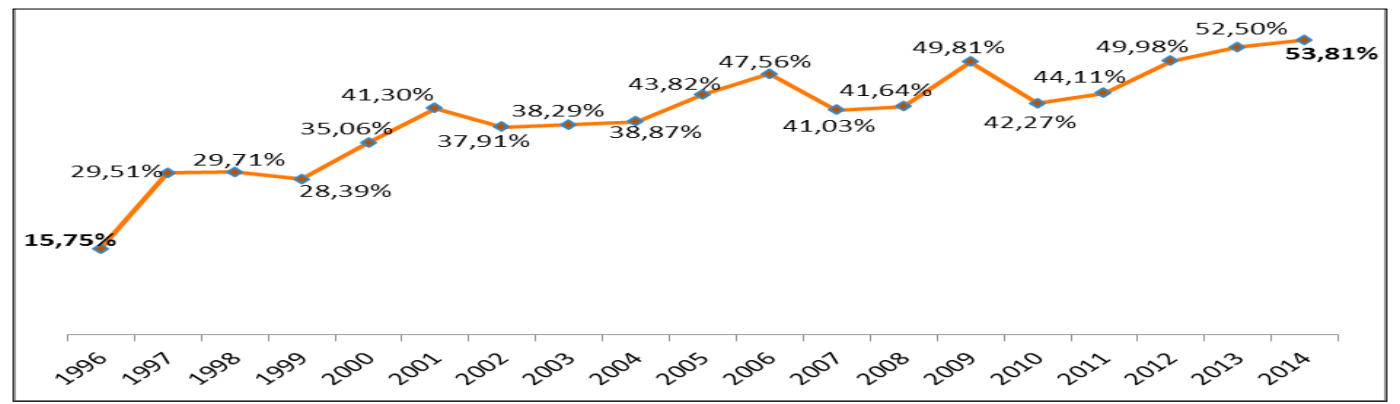

Nota: informações da exportação de soja em grão a partir da cesta de produtos: soja para semeadura; outros grãos de soja mesmo triturados; soja mesmo triturada, para semeadura; soja mesmo triturada, exceto para semeadura. Valores convertidos para a moeda nacional corrente, taxa de câmbio: dólar dos Estados Unidos da América, obtida através de elaboração de média para cada ano pesquisado. Dados disponíveis nos anexos: Tabela 3

Fonte: elaborado pela autora com base em ALICEWEB, 2016; IBGE, 2016; BACEN, 2016.

Quando analisados os dados de exportação do grão, em valores monetários, as variações percentuais e o crescimento são superiores e essa diferença está associada às variações na taxa de câmbio no período. Em 1996 foram exportados 1,022 bilhões reais e em 2014 os valores chegaram a $R \$ 54,797$ bilhões, apresentando um crescimento de $22 \%$ ao ano, o aumento mais expressivo (159\%) se deu entre os anos de 1996 e 1997(vide anexo: Tabela 3).

Os produtos do complexo da soja lideraram as vendas ao exterior, representando $35,73 \%$ e o principal mercado importador desses produtos foi a China, apresentando um crescimento de 472,3\% entre os anos de 2007 a 2013 no volume importado do Brasil (BRASIL, 2014).

O agronegócio exerceu forte influência no equilíbrio das contas nacionais ao longo dos anos e no intuito de aprofundar o conhecimento a respeito é necessário identificar qual a participação do estado do Rio Grande do Sul nessa evolução. 


\subsection{Produção e exportação de soja no Rio Grande do Sul: 1996-2014}

Balança comercial total do Rio Grande do Sul apresentou sucessivos resultados superavitários, crescendo $11 \%$ ao ano (vide anexo: Tabela 5), exercendo forte influência nos saldos comerciais brasileiros e a evolução da sua participação está disposta no Gráfico 7.

Gráfico 7 - Participação do Rio Grande do Sul na balança comercial total brasileira de 1996 a 2014

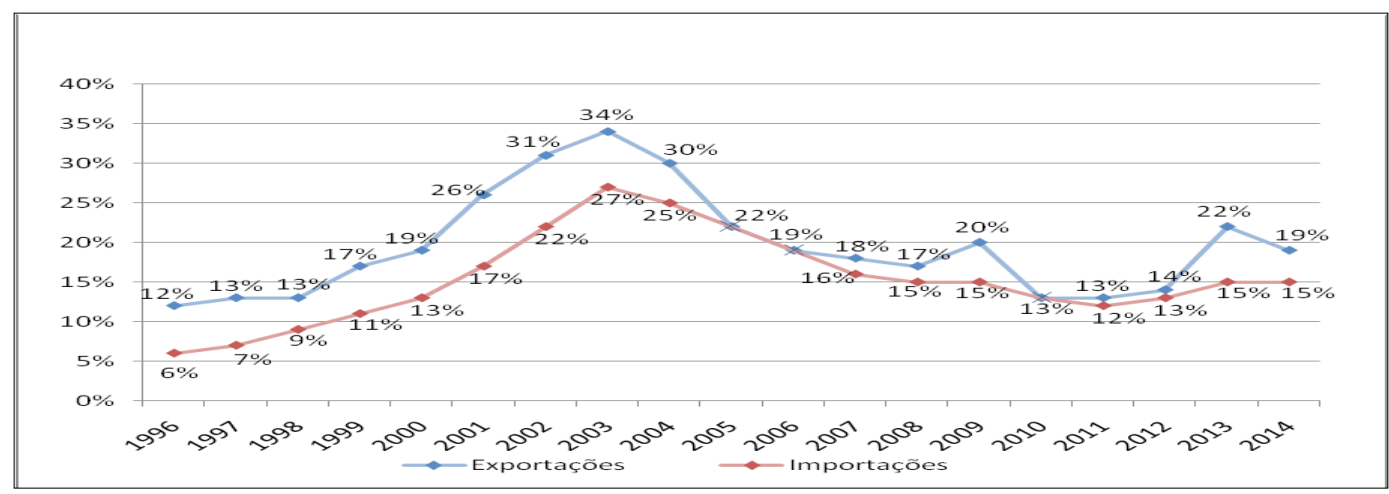

Nota: valores convertidos para a moeda nacional corrente, taxa de câmbio: dólar dos Estados Unidos da América, obtida através de elaboração de média para cada ano pesquisado. Dados disponíveis nos anexos: Tabela 4

Fonte: elaborado pela autora com base em Fiergs (2016).

Em 1996 a participação do Estado foi de 12\% nas exportações e 6\% nas importações, chegando a 34\% em 2003 e o agronegócio foi principal influenciador, sendo que no ano de 1996, 72\% das exportações gaúchas tiveram origem neste setor, e apesar de sua participação reduzir ao longo da série, o menor índice se deu em 2013 (52\%) e no ano de 2014 chegou 65\% conforme dados do Gráfico 8. 
Gráfico 8 - Participação do Agronegócio na balança comercial total do Rio Grande do Sul de 1996 a 2014

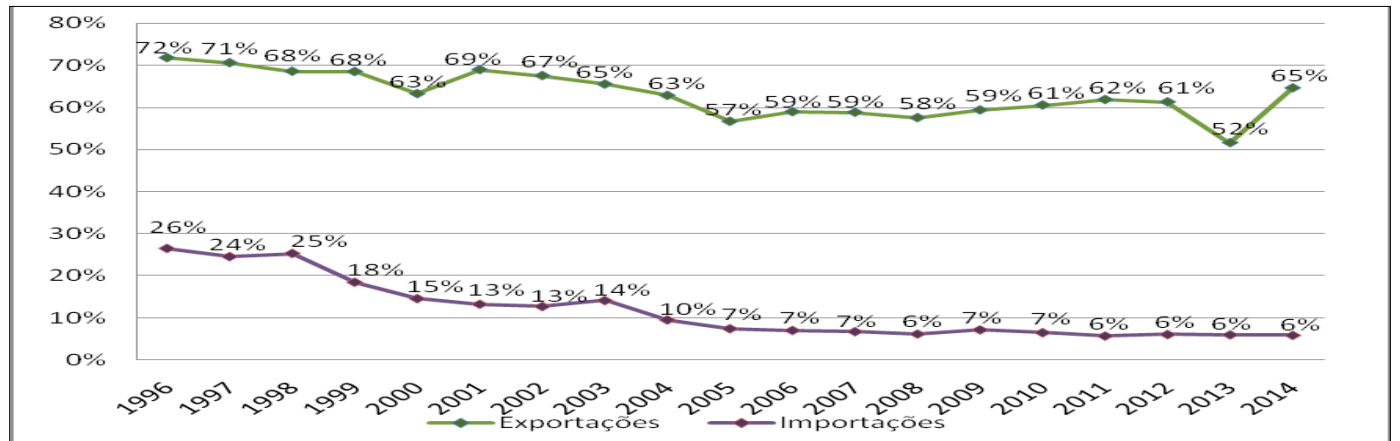

Nota: valores convertidos para a moeda nacional corrente, taxa de câmbio: dólar dos Estados Unidos da América, obtida através de elaboração de média para cada ano pesquisado. Dados disponíveis nos anexos: Tabela 5

Fonte: elaborado pela autora com base em Fiergs (2016).

Assim como no cenário nacional, os principais produtos exportados no Rio Grande do Sul são os do complexo da soja (FEIX; LEUSIN JÚNIOR, 2015, p. 11). Inicialmente a contribuição da soja nas exportações do agronegócio era mínima e foi evoluindo com o passar dos anos. Em contra partida, nas importações, na maioria dos anos pesquisados não foram importados grãos, e quando se fez necessário não ultrapassou $7 \%$ do total adquirido pelo setor, conforme os dados expostos no Gráfico 9.

Gráfico 9 - Participação da soja em grão nas na balança comercial do agronegócio no Rio Grande do Sul de 1996 a 2014

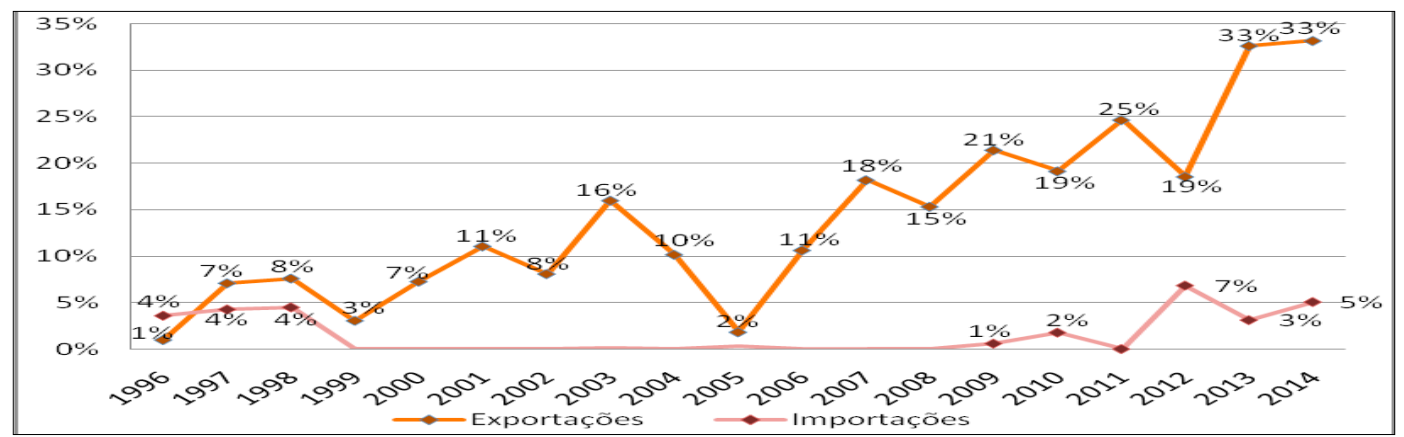

Nota: valores convertidos para a moeda nacional corrente, taxa de câmbio: dólar dos Estados Unidos da América, obtida através de elaboração de média para cada ano pesquisado. Dados disponíveis nos anexos: Tabela 6

Fonte: elaborado pela autora com base em Fiergs (2016). 
Quanto à contribuição do Estado no volume produzido no país, representada no Gráfico 10, a sua participação oscilou entre $11,18 \%$ e $20,64 \%$, e as suas menores participações aconteceram nos anos de $2005(4,78 \%)$ e $2012(9,03 \%)$ quando a estiagem comprometeu drasticamente a sua produção, mesmo com tantas oscilações cresceu $16 \%$ ao ano.

Gráfico 10 - Participação relativa do Rio Grande do Sul na produção brasileira de soja de 1996 a 2014

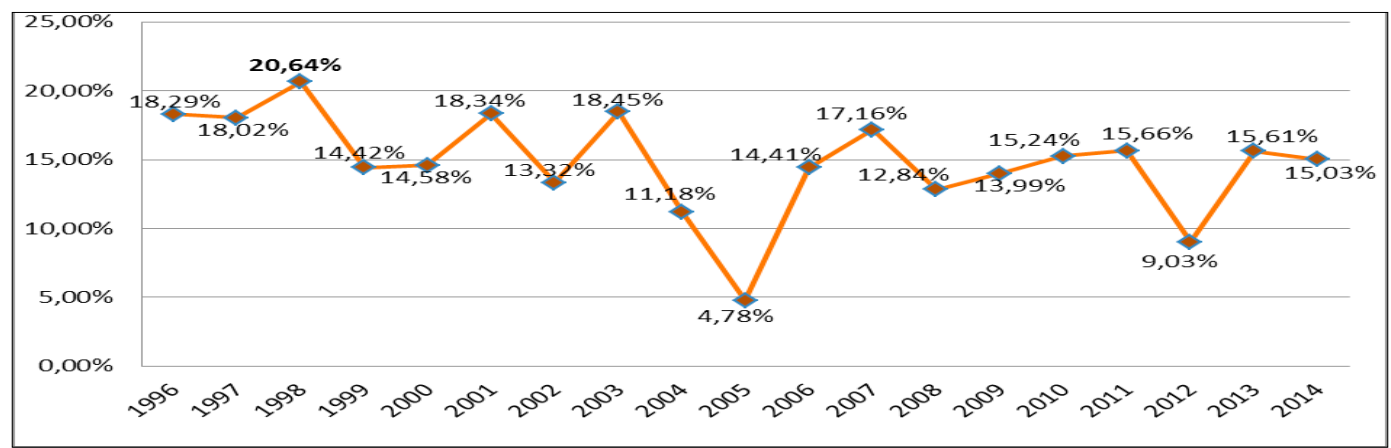

Nota: dados disponíveis nos anexos: Tabela 7

Fonte: elaborado pela autora com base em IBGE (2016).

No Gráfico 11 é possível visualizar a evolução da produção do grão no Estado, que apresentou um crescimento de 6\% ao ano. No ano de 1997 o Rio Grande do Sul produziu apenas $12 \%$ a mais que em 1996, mas exportou $607 \%$ a mais, sugerindo a participação da Lei Kandir nesse aumento, vide Tabela 1.

Gráfico 11 - Evolução da produção de soja no Rio Grande do Sul de 1996 a 2014

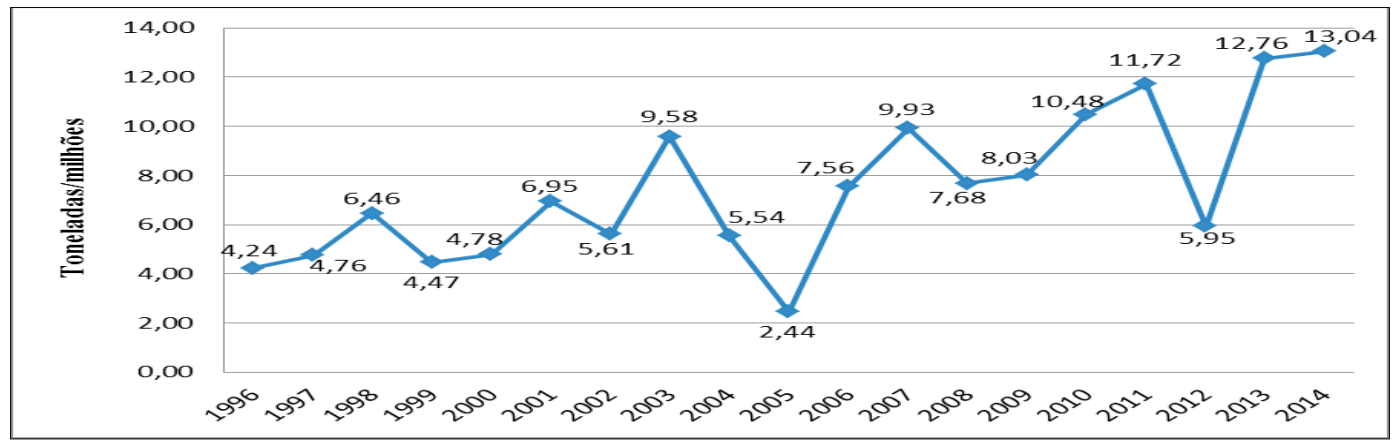

Nota: dados disponíveis nos anexos: Tabela 7

Fonte: elaborado pelos autores com base em IBGE (2016). 
A quantidade exportada do grão cresceu $22 \%$ ao ano, apesar das oscilações na produção, conforme dados da Tabela 1, apresentando importantes reduções nos anos de 1999, 2005 e 2012, respectivamente $-53 \%,-80 \%,-39 \%$, quando a estiagem reduziu a produção, e no ano de 2014, exportou 59,03\% da sua produção.

A participação do Estado nas exportações brasileiras apresentou oscilações, em 1996 foi responsável por apenas 3,89\%, saltando para 12,88\% em 1997, já nos anos de 1999, 2005 e 2012, a sua participação foi de, $6,77 \%, 1,96 \%$ e $10,90 \%$, respectivamente, sendo que o pior resultado foi em 2005 foi e o seu recorde de participação ocorreu em 2007 (23,17\%), conforme dados do Gráfico 12.

Tabela 1 - Evolução da produção e volume de exportação de soja no Rio Grande do Sul de 1996 a 2014

\begin{tabular}{c|r|r|c}
\hline Anos & Produção $(\mathrm{t})$ & Exportação $(\mathrm{t})^{1}$ & $\begin{array}{c}\text { Participação das exportações } \\
\text { na produção }\end{array}$ \\
\hline 1996 & 4.235 .532 & 141.933 & $3,35 \%$ \\
1997 & 4.755 .000 & 1.003 .239 & $21,10 \%$ \\
1998 & 6.462 .515 & 1.266 .184 & $19,59 \%$ \\
1999 & 4.467 .110 & 595.856 & $13,34 \%$ \\
2000 & 4.783 .895 & 1.400 .859 & $29,28 \%$ \\
2001 & 6.951 .830 & 2.837 .486 & $40,82 \%$ \\
2002 & 5.610 .518 & 1.794 .444 & $31,98 \%$ \\
2003 & 9.579 .297 & 3.790 .086 & $39,57 \%$ \\
2004 & 5.541 .714 & 2.198 .251 & $39,67 \%$ \\
2005 & 2.444 .540 & 439.229 & $17,97 \%$ \\
2006 & 7.559 .291 & 3.278 .282 & $43,37 \%$ \\
2007 & 9.929 .005 & 5.500 .862 & $55,40 \%$ \\
2008 & 7.679 .939 & 3.515 .963 & $45,78 \%$ \\
2009 & 8.025 .322 & 4.853 .788 & $60,48 \%$ \\
2010 & 10.480 .026 & 4.683 .882 & $44,69 \%$ \\
2011 & 11.717 .548 & 5.866 .515 & $50,07 \%$ \\
2012 & 5.945 .243 & 3.586 .545 & $60,33 \%$ \\
2013 & 12.756 .577 & 7.872 .785 & $61,72 \%$ \\
2014 & 13.041 .720 & 7.698 .483 & $59,03 \%$ \\
\hline
\end{tabular}

Nota: ${ }^{1}$ informações da exportação de soja em grão a partir da cesta de produtos: soja para semeadura; outros grãos de soja mesmo triturados; soja mesmo triturada, para semeadura; soja mesmo triturada, exceto para semeadura.

Fonte: elaborado pelos autores com base em Aliceweb (2016b); IBGE (2016); Bacen (2016). 
Gráfico 12 - Participação do Rio Grande do Sul nas exportações brasileiras de soja de 1996 a 2014

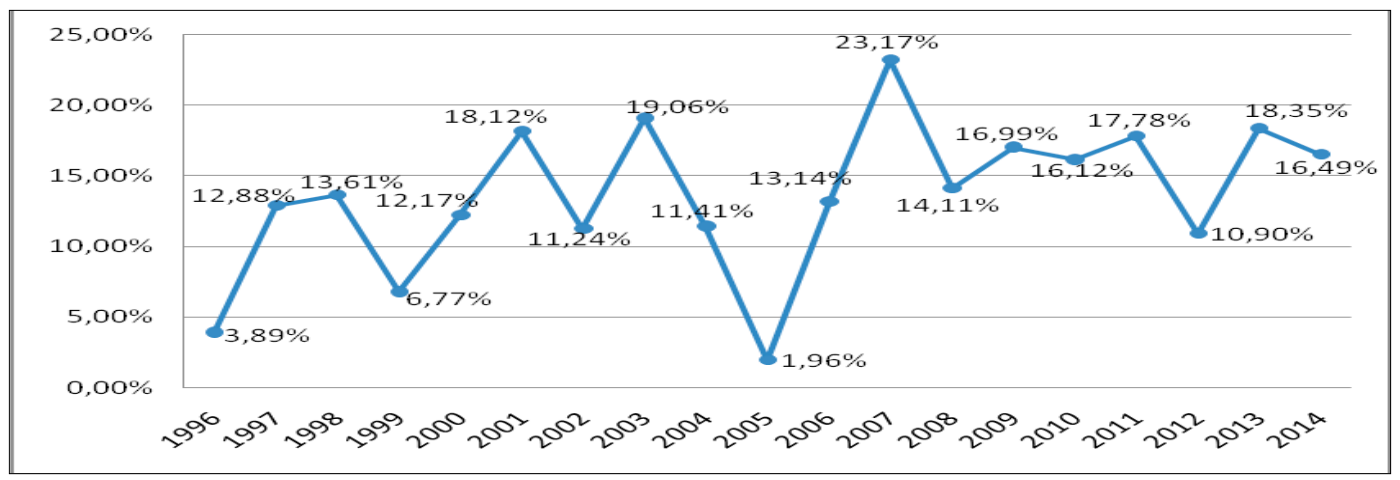

Nota: informações da exportação de soja em grão a partir da cesta de produtos: soja para semeadura; outros grãos de soja mesmo triturados; soja mesmo triturada, para semeadura; soja mesmo triturada, exceto para semeadura. Dados disponíveis nos anexos: Tabela 8

Fonte: elaborado pelos autores com base em Aliceweb (2016b).

\subsection{Produção e exportação de soja no Corede Produção de 1997 a 2014}

Os resultados comerciais superavitários, totais e da soja, no Corede Produção apresentaram um crescimento anual de $16 \%$, e de $26 \%$, respectivamente, sendo este último justificado pela ausência de importações do grão de 1997 a 2011, além da expansão das exportações, principalmente nos anos de 2003, e de 2011 a 2014, (vide anexos: Tabela 9).

O aumento das exportações do grão tem relação com crescimento da área de cultivo, que foi de $1,55 \%$ ao ano, sendo que em 2014, foi $30 \%$ maior que 1997 , conforme o Gráfico 13, e em média, a sua participação no total do Estado foi $7 \%$ (vide anexo: Tabela 10). 
Gráfico 13 - Evolução da área destinada ao cultivo de soja no COREDE Produção de 1997 a 2014

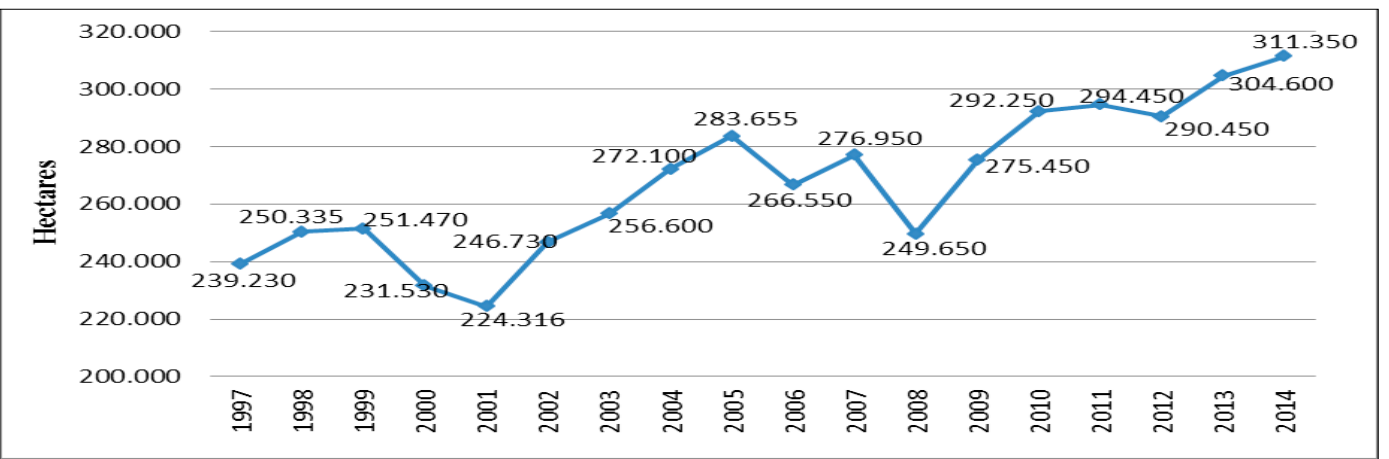

Nota: dados disponíveis nos anexos: Tabela 10

Fonte: elaborado pelos autores com base em IBGE (2016).

Já na produção, a participação do Corede Produção no total do Estado foi de $8 \%$, em média, com um crescimento de $12 \%$ ao ano, enquanto que no Estado, que foi de 16\% (vide anexos: Tabela 12). Altamente produtivo colheu 3,20 t/ha em 2011 enquanto que no restante do Estado foi de 2,85 toneladas (Gráfico 14).

Gráfico 14 - Produtividade de soja no Rio Grande do Sul e no COREDE Produção de 1997 a 2014

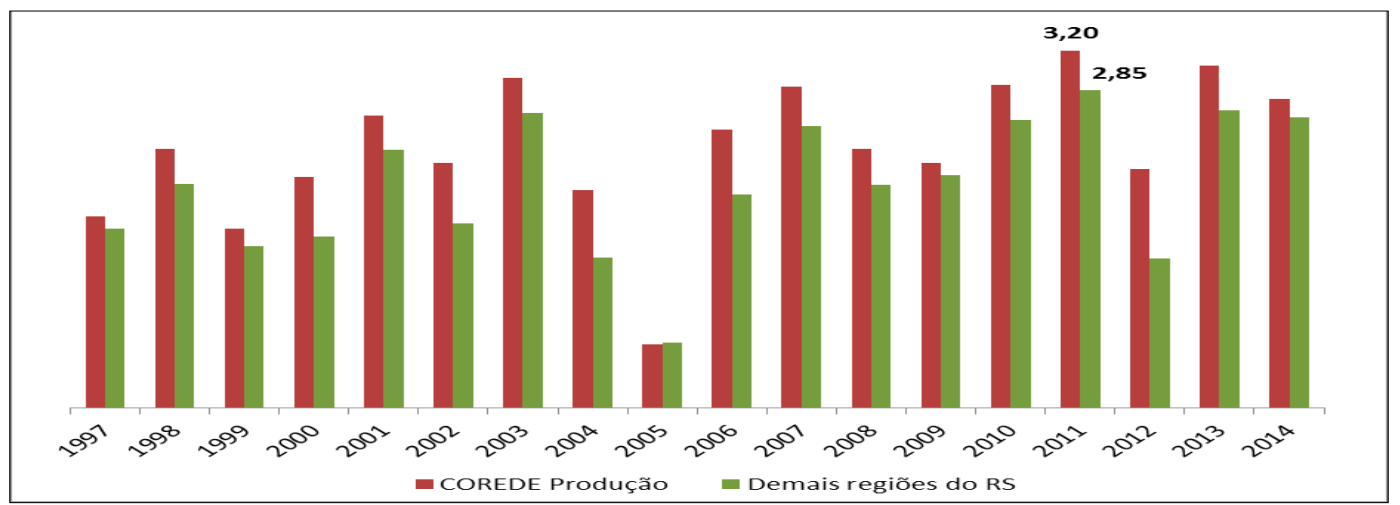

Nota: dados disponíveis nos anexos - Tabela 11.

Fonte: elaborado pelos autores com base em IBGE (2016).

As variações nas quantidades produzidas do grão dispostas no Gráfico 15 apontam que em 1997, 410.938 toneladas foram colhidas na região, e em 2014 foi $110 \%$ maior (863.585 t). 
Gráfico 15 - Evolução da produção de soja no Corede Produção de 1997 a 2014

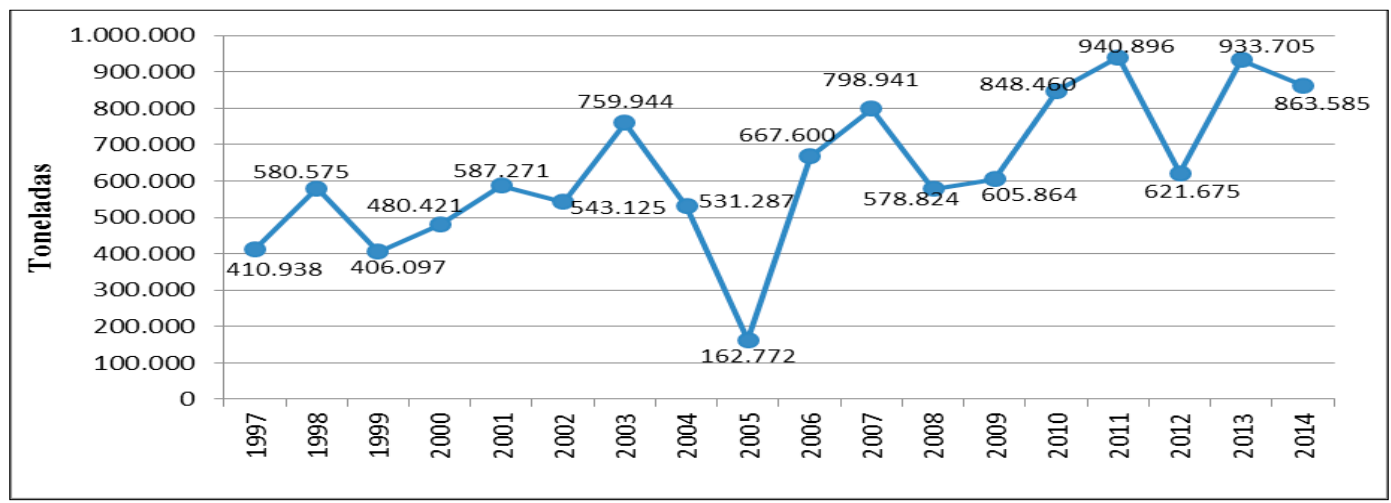

Nota: dados disponíveis nos anexos: Tabela 12

Fonte: elaborado pelos autores com base em IBGE (2016).

Quanto às exportações, em 1997, apenas 9\% da sua produção foram exportados, e até o ano de 2002 os índices de participação foram inferiores a 10\%, sugerindo que a Lei Kandir não às influenciou de imediato. De 2003 a 2010 o máximo exportado foi $23 \%$ da sua produção, porém no ano de 2011 , atingiu $49 \%$, chegando a $99 \%$ em 2014 (Gráfico 16).

Gráfico 16 - Evolução da participação das exportações na produção de soja no COREDE Produção de 1997 a 2014

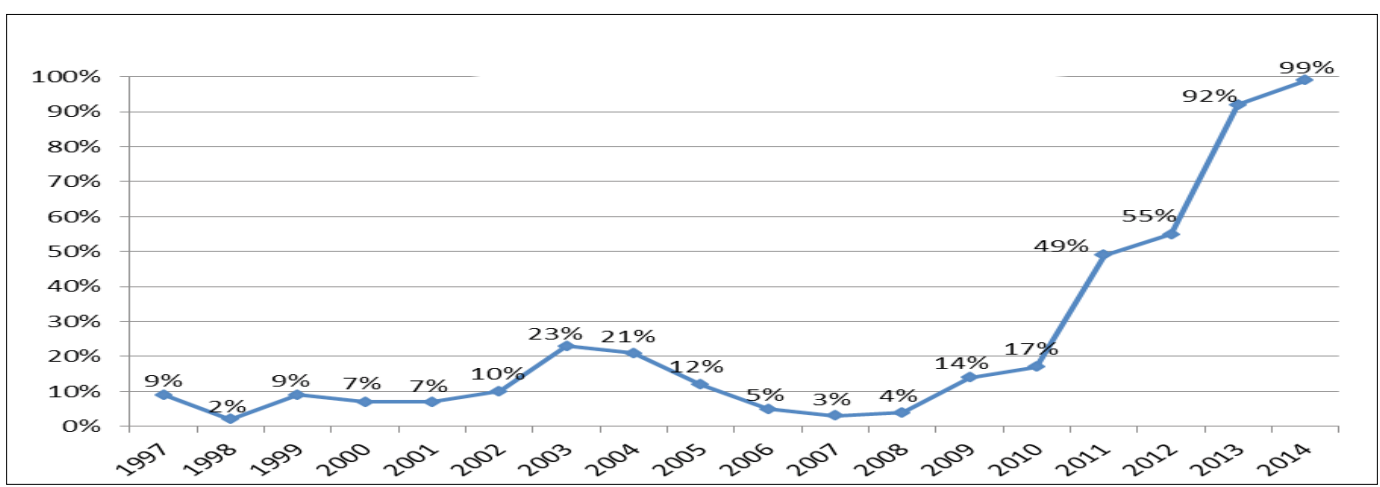

Nota: informações da exportação de soja em grão a partir da cesta de produtos: soja para semeadura; outros grãos de soja mesmo triturados; soja mesmo triturada, para semeadura; soja mesmo triturada, exceto para semeadura. Valores convertidos para a moeda nacional corrente, taxa de câmbio: dólar dos Estados Unidos da América, obtida através de elaboração de média para cada ano pesquisado. Dados disponíveis nos anexos: Tabela 13.

Fonte: elaborado pela autora com base em Aliceweb (2016b). 
Os municípios de Carazinho, Casca, Marau e Passo Fundo, são os que efetuam as operações de exportação, e de 1997 a 2010 a quantidade exportada por eles foi inferior à sua produção, mas a partir de 2011 mais de $100 \%$ da sua produção, demonstrando que outros municípios contribuíram para esse aumento, conforme demonstrado no Gráfico 17.

\section{Gráfico 17 - Participação das exportações na produção de soja nos municípios de Carazinho, Casca, Marau e Passo Fundo de 1997 a 2014.}

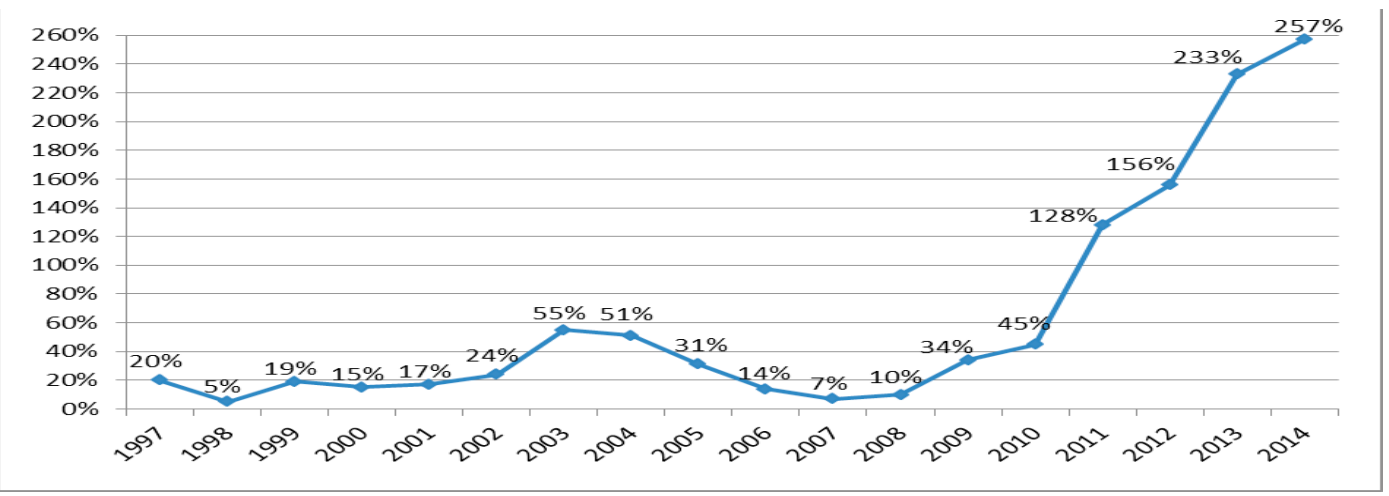

Nota: informações da exportação de soja em grão a partir da cesta de produtos: soja para semeadura; outros grãos de soja mesmo triturados; soja mesmo triturada, para semeadura; soja mesmo triturada, exceto para semeadura. Dados disponíveis nos anexos: Tabela 14

Fonte: elaborado pelos autores com base em Aliceweb (2016b); IBGE (2016).

\subsection{Lei Kandir: Estimativas de perdas da arrecadação de ICMS sobre as exportações de soja do COREDE Produção de 1997 a 2014}

Apesar da Lei Kandir não ter influenciado as exportações de soja no Corede Produção, ela causou impactos relevantes aos cofres públicos, conforme demonstrado na Tabela 2. O valor estimado acumulado de ICMS que o Rio Grande do Sul deixou arrecadar foi de $\mathrm{R} \$ 375.188 .090,31$, correspondendo a $16,09 \%$ do total de perdas liquidas do Estado, que acumula $R \$ 23,3$ bilhões (SEFAZ, 2015).

Entre os anos de 2011 e 2014, o Corede exportou a maior quantidade da sua produção e o maior percentual de repasse do seguro receita foi de $13,1 \%$, acumulando um total de perdas de $\mathrm{R} \$ 90.760 .875,00$, ou seja, $83,7 \%$ das perdas de arrecadação de ICMS ocorreram nesses anos. 
Tabela 2 - Estimativa de perdas de arrecadação de ICMS do Rio Grande do Sul nas exportações de soja no Corede Produção: 1997-2014 (R\$)

\begin{tabular}{l|r|r|r|r|r}
\hline Ano & Exportações ${ }^{1}$ & $\begin{array}{c}\text { Estimativa de } \\
\text { arrecadação de ICMS } \\
(13 \%)(\mathrm{a})\end{array}$ & $\begin{array}{c}\text { Repasse para o } \\
\text { Estado }\end{array}$ & $\begin{array}{c}\text { Valor repassado ao } \\
\text { RS (b) }\end{array}$ & $\begin{array}{r}\text { Perdas do RS nas } \\
\text { exportações do } \\
\text { COREDE (a-b) }\end{array}$ \\
\hline 1997 & $12.559 .717,89$ & $1.632 .763,33$ & $9,0 \%$ & $146.948,70$ & $1.485 .814,63$ \\
1998 & $3.528 .024,00$ & $458.643,12$ & $79,5 \%$ & $364.621,28$ & $94.021,84$ \\
1999 & $14.389 .964,07$ & $1.870 .695,33$ & $59,1 \%$ & $1.105 .580,94$ & $765.114,39$ \\
2000 & $13.881 .254,71$ & $1.804 .563,11$ & $54,9 \%$ & $990.705,15$ & $813.857,96$ \\
2001 & $21.414 .756,12$ & $2.783 .918,30$ & $66,9 \%$ & $1.862 .441,34$ & $921.476,96$ \\
2002 & $32.591 .355,80$ & $4.236 .876,25$ & $41,4 \%$ & $1.754 .066,77$ & $2.482 .809,48$ \\
2003 & $118.626 .760,38$ & $15.421 .478,85$ & $31,4 \%$ & $4.842 .344,36$ & $10.579 .134,49$ \\
2004 & $93.121 .857,66$ & $12.105 .841,50$ & $29,0 \%$ & $3.510 .694,03$ & $8.595 .147,46$ \\
2005 & $10.946 .141,65$ & $1.422 .998,41$ & $38,1 \%$ & $542.162,40$ & $880.836,02$ \\
2006 & $17.375 .035,13$ & $2.258 .754,57$ & $30,0 \%$ & $677.626,37$ & $1.581 .128,20$ \\
2007 & $11.621 .238,85$ & $1.510 .761,05$ & $20,6 \%$ & $311.216,78$ & $1.199 .544,27$ \\
2008 & $18.079 .795,22$ & $2.350 .373,38$ & $20,1 \%$ & $472.425,05$ & $1.877 .948,33$ \\
2009 & $79.603 .618,30$ & $10.348 .470,38$ & $17,3 \%$ & $1.790 .285,38$ & $8.558 .185,00$ \\
2010 & $95.495 .954,46$ & $12.414 .474,08$ & $16,2 \%$ & $2.011 .144,80$ & $10.403 .329,28$ \\
2011 & $404.512 .208,35$ & $52.586 .587,08$ & $13,1 \%$ & $6.888 .842,91$ & $45.697 .744,18$ \\
2012 & $336.504 .253,23$ & $43.745 .552,92$ & $11,1 \%$ & $4.855 .756,37$ & $38.889 .796,55$ \\
2013 & $983.300 .686,87$ & $127.829 .089,29$ & $10,4 \%$ & $13.294 .225,29$ & $114.534 .864,01$ \\
2014 & $1.068 .325 .159,37$ & $138.882 .270,72$ & $9,4 \%$ & $13.054 .933,45$ & $125.827 .337,27$ \\
Total & $3.335 .877 .782,06$ & $433.664 .111,67$ & & $\mathbf{5 8 . 4 7 6 . 0 2 1 , 3 5}$ & $\mathbf{3 7 5 . 1 8 8 . 0 9 0 , 3 1}$ \\
\hline
\end{tabular}

Nota: ${ }^{1}$ informações da exportação de soja em grão a partir da cesta de produtos: soja para semeadura; outros grãos de soja mesmo triturados; soja mesmo triturada, para semeadura; soja mesmo triturada, exceto para semeadura. Valores convertidos para a moeda nacional corrente, taxa de câmbio: dólar dos Estados Unidos da América, obtida através de elaboração de média para cada ano pesquisado.

Fonte: elaborado pelos autores com base em Aliceweb (2016b); Receita Estadual (2015).

Considerando que a estimativa de arrecadação proporcional à exportação de soja no Corede possui um valor acumulado em $\mathrm{R} \$ 433.664 .111,67$, o valor que deveria ser repassado aos municípios (25\%) seria de $\mathrm{R} \$ 108.416 .027,92$. No entanto, os percentuais repassados da União apontam que desse montante, apenas $\mathrm{R} \$$ 14.619.005,34 estariam disponíveis aos municípios exportadores ou seja, as perdas reais desses são de $\mathrm{R} \$ 108.379 .285,26$, conforme disposto na Tabela 3. 
Tabela 3 - Estimativa de perdas dos repasses de ICMS do Estado aos municípios exportadores do COREDE Produção: 1997-2014 (R\$)

\begin{tabular}{c|c|c|c|c|c}
\hline Ano & $\begin{array}{c}\text { Estimativa de } \\
\text { arrecadação de ICMS } \\
(13 \%)\end{array}$ & $\begin{array}{c}\text { Repasse para os } \\
\text { municípios (25\%) (a) }\end{array}$ & $\begin{array}{c}\text { Repasse para } \\
\text { o Estado }\end{array}$ & $\begin{array}{c}\text { Estimativa do valor } \\
\text { compensado ao } \\
\text { RS repassado ao } \\
\text { COREDE (b) }\end{array}$ & $\begin{array}{c}\text { Perdas COREDE } \\
(\mathrm{a}-\mathrm{b})\end{array}$ \\
\hline 1997 & $1.632 .763,33$ & $408.190,83$ & $9,00 \%$ & $36.737,17$ & $371.453,66$ \\
1998 & $458.643,12$ & $114.660,78$ & $79,50 \%$ & $91.155,32$ & $114.659,99$ \\
1999 & $1.870 .695,33$ & $467.673,83$ & $59,10 \%$ & $276.395,23$ & $467.673,24$ \\
2000 & $1.804 .563,11$ & $451.140,78$ & $54,90 \%$ & $247.676,29$ & $451.140,23$ \\
2001 & $2.783 .918,30$ & $695.979,57$ & $66,90 \%$ & $465.610,34$ & $695.978,91$ \\
2002 & $4.236 .876,25$ & $1.059 .219,06$ & $41,40 \%$ & $438.516,69$ & $1.059 .218,65$ \\
2003 & $15.421 .478,85$ & $3.855 .369,71$ & $31,40 \%$ & $1.210 .586,09$ & $3.855 .369,40$ \\
2004 & $12.105 .841,50$ & $3.026 .460,37$ & $29,00 \%$ & $877.673,51$ & $3.026 .460,08$ \\
2005 & $1.422 .998,41$ & $355.749,60$ & $38,10 \%$ & $135.540,60$ & $355.749,22$ \\
2006 & $2.258 .754,57$ & $564.688,64$ & $30,00 \%$ & $169.406,59$ & $564.688,34$ \\
2007 & $1.510 .761,05$ & $377.690,26$ & $20,60 \%$ & $77.804,19$ & $377.690,06$ \\
2008 & $2.350 .373,38$ & $587.593,34$ & $20,10 \%$ & $118.106,26$ & $587.593,14$ \\
2009 & $10.348 .470,38$ & $2.587 .117,59$ & $17,30 \%$ & $447.571,34$ & $2.587 .117,42$ \\
2010 & $12.414 .474,08$ & $3.103 .618,52$ & $16,20 \%$ & $502.786,20$ & $3.103 .618,36$ \\
2011 & $52.586 .587,08$ & $13.146 .646,77$ & $13,10 \%$ & $1.722 .210,73$ & $13.146 .646,64$ \\
2012 & $43.745 .552,92$ & $10.936 .388,23$ & $11,10 \%$ & $1.213 .939,09$ & $10.936 .388,12$ \\
2013 & $127.829 .089,29$ & $31.957 .272,32$ & $10,40 \%$ & $3.323 .556,32$ & $31.957 .272,22$ \\
2014 & $138.882 .270,72$ & $34.720 .567,68$ & $9,40 \%$ & $3.263 .733,36$ & $34.720 .567,59$ \\
Total & $433.664 .111,67$ & $108.416 .027,92$ & & $14.619 .005,34$ & $\mathbf{1 0 8 . 3 7 9 . 2 8 5 , 2 6}$ \\
\hline
\end{tabular}

Nota: valores convertidos para a moeda nacional corrente, taxa de câmbio: dólar dos Estados Unidos da América, obtida através de elaboração de média para cada ano pesquisado.

Fonte: elaborado pelos autores com base em Aliceweb (2016b); Receita Estadual (2015).

Por não existir informações de exportação de cada município que compõe o Corede, estimou-se, em função da sua produção anual de soja, o seu valor relativo de perdas, visualizado no Gráfico 18. 
Gráfico 18 - Perdas de repasse de ICMS do Estado a cada município do Corede Produção em função da sua produção de soja acumulada no período de 1997-2014

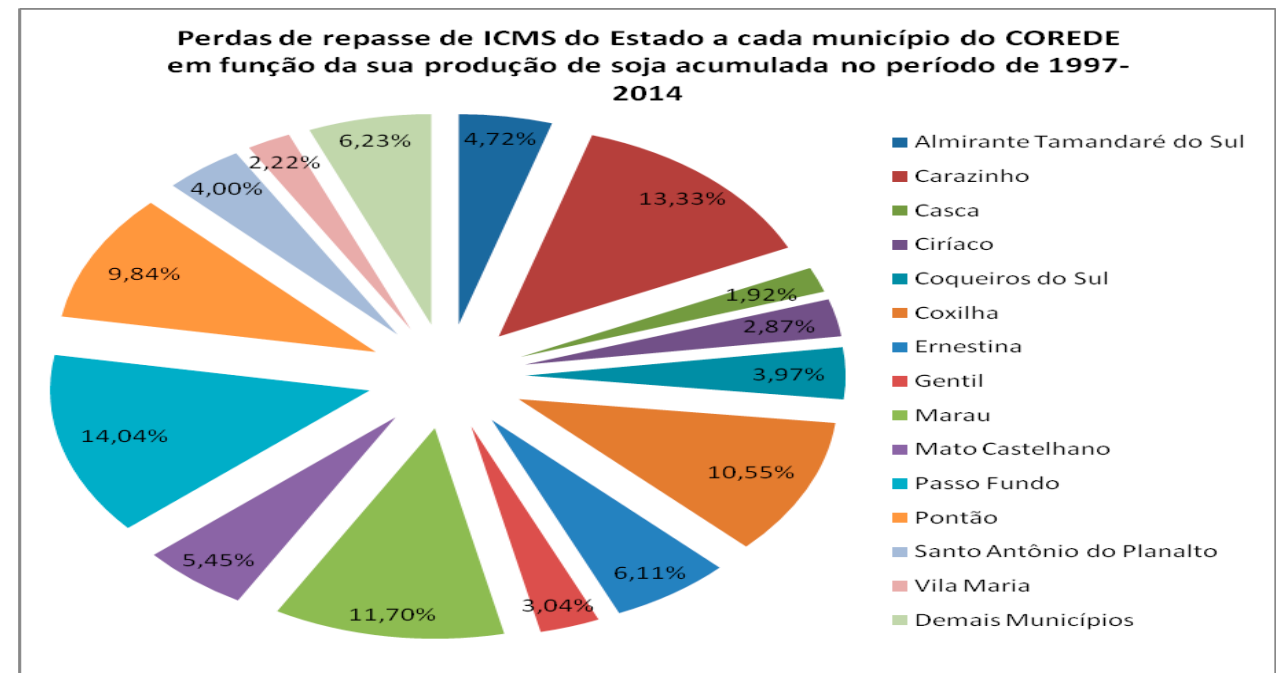

Fonte: elaborado pelos autores com base em IBGE (2016).

Os municípios de Coxilha e Pontão participam com 10,55\% e 9,84\% respectivamente, da produção de soja no Corede, superando o município de Casca, porém não há informações do percentual da sua produção destinado ao exterior, afirmando a importância da disponibilização dessas informações, permitindo mapear a participação cada município nas exportações do Estado. Os valores monetários acumulados, correspondente a cada município, dispostos na Tabela 4 evidenciam os impactos na arrecadação tributária de ICMS.

Caso fossem disponibilizadas as informações de exportação de cada município, esses poderiam pressionar o Estado e, consequentemente, o governo federal a repensar sobre essa política de incentivo às exportações, apresentando, com informações concretas os prejuízos municipais provocados pela ineficiência do seu sistema compensatório. Se tanto a lei quanto o sistema de compensação fossem revistos e reformulados, esses valores poderiam estar disponíveis às prefeituras para fomentar o desenvolvimento dos municípios. 
Tabela 4 - Perdas de repasse de ICMS do Estado a cada município do Corede em função da sua produção de soja acumulada no período de 1997-2014

\begin{tabular}{l|r|r|rr}
\hline \multicolumn{1}{c|}{ Município } & $\begin{array}{c}\text { Produção } \\
\text { Acumulada (t) }\end{array}$ & $\begin{array}{c}\text { Participação na produção } \\
\text { total }(\mathrm{a})\end{array}$ & $\begin{array}{c}\text { Perdas de repasse do ICMS } \\
\left(\mathrm{a}^{*} \mathrm{R} \$ 108.416 .027,92\right)\end{array}$ \\
\hline Almirante Tamandaré do Sul & 534.390 & $4,72 \%$ & $\mathrm{R} \$$ & $5.117 .165,12$ \\
Camargo & 197.610 & $1,75 \%$ & $\mathrm{R} \$$ & $1.892 .256,59$ \\
Carazinho & 1.509 .517 & $13,33 \%$ & $\mathrm{R} \$$ & $14.454 .701,14$ \\
Casca & 217.096 & $1,92 \%$ & $\mathrm{R} \$$ & $2.078 .848,93$ \\
Ciríaco & 324.690 & $2,87 \%$ & $\mathrm{R} \$$ & $3.109 .138,16$ \\
Coqueiros do Sul & 449.250 & $3,97 \%$ & $\mathrm{R} \$$ & $4.301 .888,94$ \\
Coxilha & 1.194 .716 & $10,55 \%$ & $\mathrm{R} \$$ & $11.440 .257,20$ \\
David Canabarro & 140.444 & $1,24 \%$ & $\mathrm{R} \$$ & $1.344 .851,40$ \\
Ernestina & 692.146 & $6,11 \%$ & $\mathrm{R} \$$ & $6.627 .791,26$ \\
Gentil & 343.995 & $3,04 \%$ & $\mathrm{R} \$$ & $3.293 .997,30$ \\
Marau & 1.324 .870 & $11,70 \%$ & $\mathrm{R} \$$ & $12.686 .574,51$ \\
Mato Castelhano & 617.250 & $5,45 \%$ & $\mathrm{R} \$$ & $5.910 .608,68$ \\
Muliterno & 82.286 & $0,73 \%$ & $\mathrm{R} \$$ & $787.947,10$ \\
Nova Alvorada & 122.373 & $1,08 \%$ & $\mathrm{R} \$$ & $1.171 .808,69$ \\
Passo Fundo & 1.589 .965 & $14,04 \%$ & $\mathrm{R} \$$ & $15.225 .048,08$ \\
Pontão & 1.114 .357 & $9,84 \%$ & $\mathrm{R} \$$ & $10.670 .762,50$ \\
Santo Antônio do Palma & 110.322 & $0,97 \%$ & $\mathrm{R} \$$ & $1.056 .411,78$ \\
Santo Antônio do Planalto & 453.318 & $4,00 \%$ & $\mathrm{R} \$$ & $4.340 .842,94$ \\
São Domingos do Sul & 14.304 & $0,13 \%$ & $\mathrm{R} \$$ & $136.970,99$ \\
Vanini & 37.276 & $0,33 \%$ & $\mathrm{R} \$$ & $356.944,27$ \\
Vila Maria & 251.805 & $2,22 \%$ & $\mathrm{R} \$$ & $2.411 .212,34$ \\
TOTAL COREDE PRODUÇÃo & 11.321 .980 & $100,00 \%$ & $\mathrm{R} \$$ & $108.416 .027,92$ \\
\hline
\end{tabular}

Nota: valores convertidos para a moeda nacional corrente, taxa de câmbio: dólar dos Estados Unidos da América, obtida através de elaboração de média para cada ano pesquisado.

Fonte: elaborado pelos autores com base em IBGE (2016).

As perdas de arrecadação do tributo proveniente da aplicação lei aos cofres estaduais dificultam a execução e a manutenção de serviços essenciais à população, que são de responsabilidade do Estado, como a garantia da infraestrutura de escoamento da produção, por exemplo, além de outros, demonstrando que os únicos beneficiários desse processo são os produtores e empresas exportadoras, que tem a sua tributação aliviada, enquanto que a população tem sido duramente prejudicada pela inviabilidade econômica desta lei, sem contar os demais setores que dependem desse tributo para a sua manutenção. Além de não promover a geração de emprego e renda, sendo que ao invés de agregar valor aos seus produtos no território nacional, ela estimula que isso seja feito nos países importadores.

\subsection{Sugestões e recomendações}

Tendo em vista a significativa perda de arrecadação de ICMS do Estado e dos municípios, repensar esse modelo de incentivo é fundamental. Visando a ganhos reais para ambas as esferas, uma possível saída seria a incorporação de políticas 
de incentivo ao processamento interno desses produtos para que se possam produzir e exportar uma gama maior de produtos com maior valor agregado, aliado à retomada, mesmo que sensível, na tributação de ICMS relativa às operações de exportação de produtos in natura ou semielaborados, na tentativa de frear a sua comercialização internacional estimulando a sua industrialização. Medidas, embasadas em estudos de viabilidade de implantação, com previsões dos seus efeitos, confrontando ganhos e perdas de cada uma delas a fim de nortear qual a melhor medida para que as unidades da federação e o país possam se posicionar mais competitivamente na exportação de produtos acabados, potencializando seu desenvolvimento interno.

\section{Considerações finais}

Um aspecto relevante evidenciado no presente estudo foi à limitação na disponibilização de estudos relacionados ao tema, possivelmente provocada pela ineficácia na divulgação de alguns dados fundamentais para a realização desses, ou seja, na sua maioria dizem respeito a estimativas, e não a dados concretos, dificultando o seu embasamento teórico.

Considerando a importância do Brasil na produção e na exportação do agronegócio e as perspectivas de crescimento previstas, monitorar a contribuição da Lei Kandir nesse cenário promissor, a fim de mensurar os prejuízos das unidades federativas é fundamental. Além disso, deve-se questionar o quanto é válido garantir o sucesso do país no comércio exterior beneficia tais unidades. O Rio Grande do Sul, que é o $3^{\circ}$ maior exportador de soja do país, vem enfrentando dificuldades financeiras, principalmente pela atual crise fiscal, reflexo da cumulatividade da dívida pública e potencializada com a recessão econômica atual, que vem afetando não só o Estado, mas o Brasil como um todo. $\mathrm{O}$ total acumulado de perdas provenientes da Lei Kandir ultrapassa os $\mathrm{R} \$ 23$ bilhões, valor que amenizaria parte dos problemas financeiros do Estado, porém a União vem enfrentando uma séria crise político-econômica, inviabilizando a regularização desse débito.

E sendo os Coredes, instrumentos fundamentais para o desenvolvimento regional a que estão inseridos, conhecer e analisar o papel de cada um de seus componentes nas exportações de produtos in natura ou semielaborados é de suma importância, pois fornece informações importantes sobre como o desenvolvimento desses é prejudicado a partir da aplicabilidade dessa lei. Realizar novos estudos que abranjam todos os produtos que também se beneficiam desse incentivo, é de suma importância para que se possa mensurar a contribuição ao rombo nos cofres públicos. 


\title{
ICMS Collection Loss estimation promoted by the kandir Law in Cordoba Production - RS: an analysis on soy exports, from 1997 to 2014
}

\begin{abstract}
Brazil and Rio Grande do Sul occupy a prominent place in the production of grains and agribusiness exports and the main products exported are those of the soybean complex, mainly the grain. The Kandir Act, which exempts ICMS taxation on export operations and products (primary products, semi-finished products or services), has a direct influence on this process. In order to measure ICMS tax losses caused by the application of this law, the objective of this study is to show Corede Produção participation in exports of soy from the State, between 1997 and 2014, characterizing its evolution, estimating its volume of Tax losses from the implementation of the law in the country. The method adopted for the collection was derived from secondary data on planted area, production, volume and export value, which were submitted to a descriptive analysis of the variables linked to exports, allowing quantification of the effects of the law in the State and in Corede. The main results obtained indicate that $16.09 \%$ of the net losses of the State, from 1997 to 2014, refer to the export of COREDE soybean and the municipal losses surpass the R \$ 108 million, demonstrating its fundamental participation in the state results.
\end{abstract}

Keywords: Soybeans. Exports. Kandir Law. ICMS.

\section{Estimativa de pérdas de arrecada de ICMS promovida por la Ley Kandir en el Corede Producción - RS: un análisis sobre las exportaciones de soja, de 1997 a 2014}

\section{Resumen}

Brasil y Rio Grande do Sul tiene un lugar destacado en la producción de granos y las exportaciones de la agroindustria y los principales productos de exportación son la soja-compleja, especialmente de granos. Posiblemente la Ley Kandir eximir del impuesto ICMS en las operaciones y productos destinados a la exportación (productos primarios, productos semielaborados o servicios) influencia directa en este proceso. Tratando de medir las pérdidas de ingresos del ICMS causadas por la aplicación de esta ley, el objetivo de este estudio es poner de relieve la participación de COREDES La producción en las exportaciones de soja de estado entre los años 1997-2014, con su evolución, la estimación de su volumen pérdidas fiscales de la aplicación de la ley en el país. El método adoptado para la recogida se produjo a partir de datos secundarios sobre la superficie sembrada, el volumen de producción y el valor de las exportaciones, que fueron sometidos a análisis descriptivo de las variables relacionadas con la exportación, lo que permite cuantificar los efectos de la ley en el estado y COREDES. Los principales resultados muestran que el $16,09 \%$ de las pérdidas netas del estado 1997-2014, se refiere a la exportación de soja y las pérdidas COREDES municipales superar los $\mathrm{R} \$ 108$ millones, lo que demuestra su papel clave en los resultados estatales.

Palabras clave: Soja. Exportaciones. Ley Kandir. ICMS.

Teoria e Evidência Econômica - a. 24, n. 50, p. 51-88, jan./jun. 2018 


\section{Notas}

1 Seguro Receita, criado para convencer os Governadores de que os estados não sofreriam prejuízos a partir da desoneração fiscal, propondo uma compensação financeira dos valores referentes a essa não arrecadação (SANTOS; MARTA, 2011).

2 Para a construção da série de dados das exportações e importações de soja em grão, utilizou-se a cesta de produtos: soja para semeadura; outros grãos de soja mesmo triturados; soja mesmo triturada, para semeadura; soja mesmo triturada, exceto para semeadura (ALICEWEB, 2015).

3 Free on Board(FOB), é um dos Termos Internacionais de Comércio (Incoterms), é utilizado exclusivamente no transporte aquaviário identificando a condição de venda praticada na transação comercial ao exterior, onde "o vendedor encerra suas obrigações e responsabilidades quando a mercadoria, desembaraçada para a exportação , é entregue, arrumada, a bordo do navio no porto de embarque, ambos indicados pelo comprador, na data ou dentro do período acordado”. Câmera de Comércio Exterior (2011).

\section{Referências}

AGROSTAT. Estatísticas de Comércio Exterior do Agronegócio Brasileiro. Ministério da Agricultura, Pecuária e Abastecimento (MAPA). 2016. Disponível em: <http://www.agricultura.gov.br/ internacional/indicadores-e-estatisticas/balanca-comercial>. Acesso em: 08 maio 2016.

ALICEWEB. Sistema de Análise das Informações de Comércio Exterior - SECEX/MDIC. 2016a. Disponível em: <http://aliceweb.mdic.gov.br/consulta-ncm/index/type/exportacaoNcm>. Acesso em: 20 mar. 2016;

ALICEWEB. Sistema de Análise das Informações de Comércio Exterior. SECEX/MDIC. Exportação 1997 - NCM 8 dígitos. 2016b. Disponível em: <http://aliceweb.mdic.gov.br//consulta-ncm/ consultar>. Acesso em 20 mar. 2016.

BACEN. Banco Central do Brasil. Taxas de câmbio. 2016. Disponível em: <http://www4.bcb.gov. br/pec/taxas/port/ptaxnpesq.asp?id=txcotacao $>$. Acesso em: 15 abr. 2016.

BENDER FILHO, Reisoli. Conta petróleo e a balança comercial brasileira: uma análise do período recente. Novos estud. - CEBRAP, n. 101, p. 79-95, 2015. Disponível em: <http://www.scielo.br/ scielo.php?script=sci_arttext\&pid=S0101-33002015000100079>. Acesso em: 12 maio 2016.

BERTÊ et al. Perfil Socioeconômico - Corede - Rio da Várzea. Boletim Geográfico do Rio Grande do Sul, Porto Alegre, n. 26, p. 737-773, fev. 2016. Disponível em: <http://revistas.fee.tche.br/index.php/boletim-geografico-rs/article/view/3752/3645>. Acesso em: 17 abr. 2016.

BRASIL, Código Tributário Nacional. Constituição Federal, Legislação Tributária / obra coletiva de autoria da Editora Revistados Tribunais. 16. ed. rev., ampl. e atual. São Paulo: Revista dos Tribunais, 2011.

BRASIL. Constituição da República Federativa do Brasil de 1988. Disponível em: <http://www. planalto.gov.br/ccivil_03/constituicao/constituicaocompilado.htm>. Acesso em: 21 maio 2016.

BRASIL. Ministério da Agricultura Pecuária e Abastecimento. Intercâmbio Comercial do Agronegócio: principais mercados de destino. 8. ed. Brasília, 2014. Disponível em: <http://www.agricultura.gov.br/internacional/publicacoes>. Acesso em: 21 nov. 2015.

BRASIL. Ministério da Agricultura, Pecuária e Abastecimento (MAPA). Agrostat: estatísticas de comércio exterior do agronegócio brasileiro. Brasília, DF, 2015. Disponível em: <http://sistemasweb.agricultura.gov.br/pages/AGROSTAT.html>. Acesso em: 18 nov. 2015. 
BRASIL. Ministério da Fazenda. Irailson Calado Santana. (Org.). Carga Tributária no Brasil 2013: análise por tributos e bases de incidência. 2014. Disponível em: <http://idg.receita.fazenda. gov.br/dados/receitadata/estudos-e-tributarios-e-aduaneiros/estudos-e-estatisticas/carga-tributaria-no-brasil/carga-tributaria-2013.pdf>. Acesso em: 18 nov. 2015.

BÜTTENBENDER, Pedro Luís; SIEDENBERG, Dieter Rugard; ALLEBRANDT, Sérgio Luís. Conselhos Regionais de Desenvolvimento (COREDES) RS: articulações regionais, referenciais estratégicos e considerações críticas. Revista Desenvolvimento Regional em Debate: Revista eletrônica do Programa de Mestrado em Desenvolvimento Regional da Universidade de Constestado, Santa Catarina, n. 1, p. 81-106, 2011. Disponível em: <http://www.periodicos.unc.br/index. php/drd/article/view/66/91>. Acesso em: 22 nov. 2015.

CAMARGOS, Marcos Antônio de. Reflexões sobre o cenário econômico brasileiro na década de 90. In: XXII Encontro Nacional de Engenharia de Produção, Curitiba/PR, 2002. Disponível em: <http://www.abepro.org.br/biblioteca/enegep2002_tr30_0918.pdf>. Acesso em: 11 maio 2016.

COMPANHIA Nacional de Abastecimento. Acompanhamento da safra brasileira de grãos, v. 3, Safra 2015/16 - segundo levantamento, Brasília, p. 1-166, novembro. Disponível em: <http:// www.conab.gov.br/OlalaCMS/uploads/arquivos/15_11_10_09_11_06_boletim_graos_novembro_2015.pdf>. Acesso em: 17 abr. 2016.

DALL'AGNOL, Amélio. A Embrapa Soja no contexto do desenvolvimento da soja no Brasil: histórico e contribuições. Brasília - DF: Embrapa, 2016. Disponível em: <http://ainfo.cnptia.embrapa. $\mathrm{br} /$ digital/bitstream/item/142568/1/Livro-EmbrapaSoja-desenvolvimento-BR-OL.pdf $>$. Acesso em: 29 maio 2016.

DIEHL, Astor Antônio; TATIM, Denise Carvalho. Pesquisa em ciências sociais aplicadas: métodos e técnicas. São Paulo: Prentice Hall, 2004.

FECOMERCIO. FEDERAÇÃO DO COMÉRCIO DE BENS, SERVIÇOS E TURISMO DO PARANÁ. Comércio Exterior: relações com o exterior e com o Mercosul. n. 6, fevereiro, 2016. Disponível em: <http://www.fecomerciopr.com.br/wp-content/uploads/2016/03/02.2016-Mercosul-e-exterior. pdf>. Acesso em: 13 maio 2016.

FEIX, Rodrigo Daniel; LEUSIN JÚNIOR, Sérgio. Painel do agronegócio no Rio Grande do Sul. Porto Alegre: FEE, 2015. Disponível em: <http://www.fee.rs.gov.br/wp-content/ uploads/2015/09/20150903painel-do-agronegocio-no-rs-2015.pdf>. Acesso em: 24 maio 2016

FIERGS. Federação das Indústrias do Estado do Rio Grande do Sul. Séries históricas. 2016. Disponível em: <http://www.fiergs.org.br/pt-br/economia/indicador-economico/com\%C3\%A9rcio-exterior >. Acesso em: 17 abr. 2016.

FINAMORE, Eduardo Belisário (Org.). Planejamento Estratégico da Região da Produção: do diagnóstico ao mapa estratégico 2008/2028. Passo Fundo: UPF Editora, 2010. Disponível em: <http://www.upf.br/cepeac/download/COREDE_livro_finamore.pdf>. Acesso em: 25 nov. 2015.

FLAVIANO, Carlos; MEDEIROS, Wilton; CARVALHO, Eveline. A balança comercial e o crescimento econômico: estudo de caso sobre o estado do ceará no período de 1994-200. In: CONVIBRA - Congresso Virtual de Administração. 2004. Disponível em: <http://www.convibra.org/2004/ pdf/173.pdf>. Acesso em: 11 maio 2016.

GIL, Antônio Carlos. Métodos e técnicas de pesquisa social. 6. ed. São Paulo: Atlas, 2008.

Teoria e Evidência Econômica - a. 24, n. 50, p. 51-88, jan./jun. 2018 
IBGE Sistema IBGE de Recuperação Automática - SIDRA. Área plantada, área colhida, quantidade produzida e valor da produção da lavoura temporária. 2016. Disponível em: <http://www. sidra.ibge.gov.br/bda/tabela/listabl. asp?c=1612\&z=p\&o=29>. Acesso em: 14 mar. 2016.

LAZZAROTTO, Joelsio José; HIRAKURI, Marcelo Hiroshi. Evolução e perspectiva de desempenho econômico associados com a produção de soja nos contextos mundial e brasileiro. Londrina: Embrapa Soja, 2009. (Documentos / Embrapa Soja, ISSN 2176-2937; n. 319). Disponível em: <https://ainfo.cnptia.embrapa.br/digital/bitstream/item/17910/1/DoC_319.pdf>. Acesso em: 20 mar. 2016.

LEITÃO, Alejandro; IRFFI, Guilherme; LINHARES, Fabricio. Avaliação dos efeitos da Lei Kandir sobre a arrecadação de ICMS no estado do Ceará. Planejamento e Políticas Públicas - Ipea, n. 39, p. 37-63, 2012. Disponível em: <http://www.ipea.gov.br/ppp/index.php/PPP/article/viewFile/314/273>. Acesso em: 22 nov. 2015.

MINISTÉRIO da Agricultura, Pecuária e Abastecimento. Complexo soja. 2016. Disponível em: <http://www.agricultura.gov.br/arq_editor/Soja(1).pdf>. Acesso em: 21 maio 2016.

MINISTÉRIO DA AGRICULTURA. Balança Comercial. 2016. Disponível em: <http://www.agricultura.gov.br/internacional/indicadores-e-estatisticas/balanca-comercial>. Acesso em: 11 maio 2016.

PAIM, Luís Henrique Pacheco. Aproveitamento de créditos de ICMS em virtude do princípio de não-cumulatividade: um estudo numa empresa atacadista. 2012. $22 \mathrm{f}$. Trabalho de Conclusão de Curso (Graduação em Ciências Contábeis) - Curso de Ciências Contábeis, Universidade Federal do Rio Grande do Sul, Porto Alegre, 2012. Disponível em: <https://www.lume.ufrgs.br/bitstream/ handle/10183/79434/000894429.pdf?sequence=1>. Acesso em: 23 nov. 2015.

PORTO ALEGRE. FUNDAÇÃO DE ECONOMIA E ESTATÍSTICA. Exportações de soja continuam batendo recordes e contribuem para crescimento de volume em outubro. 2015. Disponível em: <http://www.fee.rs.gov.br/indicadores/indice-das-exportacoes/destaque-do-mes/>. Acesso em: 21 nov. 2015.

RECEITA ESTADUAL. Secretaria da Fazenda do Estado do Rio Grande do Sul. SEFAZ/RS. Demonstrativo das desonerações fiscais do RS: nota técnica, resultados em 2014 e retrospectiva histórica. 2015. Disponível em: <https:/www.sefaz.rs.gov.br/Incoming/Nota\%20T\%C3\%A9cnica\%20 e\%20Demonstrativo\%20Desonera\%C3\%A7\%C3\%B5es\%202014.pdf>. Acesso em: 29 maio 2016.

RIO GRANDE DO SUL. Decreto n 37.699, de 26 de agosto de 1997. Aprova o Regulamento do Imposto sobre Operações Relativas à Circulação de Mercadorias e sobre Prestações de Serviços de Transporte Interestadual e Intermunicipal e de Comunicação (RICMS). Decreto $N^{\circ}$ 37.699, de 26 de Agosto de 1997(regulamento de ICMS). Disponível em: <http://www.legislacao.sefaz. rs.gov.br/Site/Document.aspx?inpKey=109362\&inpCodDispositive;=\&inpDsKeywords=37.699>. Acesso em: 24 nov. 2015.

SANTOS, Dannielle Almeida dos; MARTA, Jose Manuel Carvalho. A Lei Kandir e o desenvolvimento de Mato Grosso: análise do período 1990-2009. Revista Brasileira de Gestão e Desenvolvimento Regional, Taubaté, v. 10, n. 1, p. 206-228, jan., 2014. Disponível em: <http://www.rbgdr. net/revista/index.php/rbgdr/article/down load/1217/366>. Acesso em: 19 nov. 2015.

TRENNEPOHL, Dilson, PAIVA, Carlos Águedo Nagel. A importância da sojicultura para o desenvolvimento da região noroeste do Rio Grande do Sul. Ensaios FEE, Porto Alegre, v. 31, Número Especial, p. 741-778, jun. 2011. Disponível em: <http://revistas.fee.tche.br/index.php/ensaios/ article/view/2578/2922>. Acesso em: 29 maio 2016.

Teoria e Evidência Econômica - a. 24, n. 50, p. 51-88, jan./jun. 2018 


\section{Anexo A - Tabelas}

Tabela 1 - Evolução e participação do complexo da soja na balança comercial do agronegócio brasileiro: 1996 a 2014 (R\$ Bilhões)

\begin{tabular}{c|c|c|c|c|c|c|c|c}
\hline \multirow{2}{*}{ Ano } & \multicolumn{3}{|c|}{ Exportações } & \multicolumn{3}{|c|}{ Importações } & \multicolumn{2}{c}{ Saldo } \\
\cline { 2 - 8 } & Agronegócio & Compl. Soja & Part. \% & Agronegócio & Compl. Soja & Part. \% & Agro. & Compl. Soja \\
\hline 1996 & 21,238 & 4,482 & 21 & 8,979 & 0,366 & 4 & 12,259 & 4,115 \\
1997 & 25,180 & 6,172 & 25 & 8,830 & 0,440 & 5 & 16,350 & 5,732 \\
1998 & 25,004 & 5,523 & 22 & 9,332 & 0,424 & 5 & 15,672 & 5,099 \\
1999 & 34,272 & 6,326 & 18 & 9,524 & 0,281 & 3 & 24,748 & 6,045 \\
2000 & 37,680 & 7,672 & 20 & 10,532 & 0,336 & 3 & 27,148 & 7,336 \\
2001 & 56,119 & 12,454 & 22 & 11,299 & 0,461 & 4 & 44,821 & 11,993 \\
2002 & 72,800 & 17,607 & 24 & 13,045 & 0,837 & 6 & 59,756 & 16,769 \\
2003 & 94,126 & 24,951 & 27 & 14,587 & 0,936 & 6 & 79,539 & 24,015 \\
2004 & 114,174 & 29,389 & 26 & 14,144 & 0,368 & 3 & 100,030 & 29,021 \\
2005 & 106,149 & 23,061 & 22 & 12,439 & 0,251 & 2 & 93,710 & 22,811 \\
2006 & 107,664 & 20,265 & 19 & 14,578 & 0,102 & 1 & 93,086 & 20,163 \\
2007 & 113,795 & 22,178 & 19 & 17,006 & 0,183 & 1 & 96,789 & 21,995 \\
2008 & 131,944 & 33,037 & 25 & 21,821 & 0,197 & 1 & 110,122 & 32,840 \\
2009 & 129,034 & 34,359 & 27 & 19,719 & 0,148 & 1 & 109,315 & 34,211 \\
2010 & 134,423 & 30,096 & 22 & 23,562 & 0,124 & 1 & 110,861 & 29,973 \\
2011 & 158,966 & 40,432 & 25 & 29,307 & 0,042 & 0 & 129,660 & 40,390 \\
2012 & 187,259 & 51,053 & 27 & 32,070 & 0,305 & 1 & 155,189 & 50,748 \\
2013 & 215,920 & 66,883 & 31 & 36,849 & 0,293 & 1 & 179,071 & 66,590 \\
2014 & 324,502 & 73,937 & 23 & 30,775 & 0,606 & 2 & 293,727 & 73,331 \\
\hline
\end{tabular}

Nota: valores convertidos para a moeda nacional corrente, taxa de câmbio: dólar dos Estados Unidos da América, obtida através de elaboração de média para cada ano pesquisado.

Fonte: elaborado pelos com base em Agrostat (2016); Fiergs (2016).

Tabela 2 - Participação da soja em grão nas exportações e importações do complexo da soja no Brasil: 1996 a 2014 - R\$ Bilhões

\begin{tabular}{|c|c|c|c|c|c|c|c}
\hline \multirow{2}{*}{ Ano } & \multicolumn{3}{|c|}{ Exportações } & \multicolumn{3}{c|}{ Importações } & Saldo Comercial \\
\cline { 2 - 7 } & Complexo da Soja & Soja grão (a) & Part. \% & Complexo da Soja & Soja grão (b) & Part. \% & Soja grão (a-b) \\
\hline 1996 & 4,482 & 1,022 & 23 & 0,366 & 0,249 & 68 & 0,773 \\
1997 & 6,172 & 2,643 & 43 & 0,440 & 0,283 & 64 & 2,361 \\
1998 & 5,523 & 2,527 & 46 & 0,424 & 0,234 & 55 & 2,293 \\
1999 & 6,326 & 2,664 & 42 & 0,281 & 0,137 & 49 & 2,526 \\
2000 & 7,672 & 4,001 & 52 & 0,336 & 0,243 & 72 & 3,758 \\
2001 & 12,454 & 6,409 & 51 & 0,461 & 0,323 & 70 & 6,085 \\
2002 & 17,607 & 8,884 & 50 & 0,837 & 0,512 & 61 & 8,372 \\
2003 & 24,951 & 13,175 & 53 & 0,936 & 0,710 & 76 & 12,465 \\
2004 & 29,389 & 15,780 & 54 & 0,368 & 0,213 & 58 & 15,566 \\
2005 & 23,061 & 13,006 & 56 & 0,251 & 0,167 & 67 & 12,839 \\
2006 & 20,265 & 12,325 & 61 & 0,102 & 0,021 & 21 & 12,304 \\
2007 & 22,178 & 13,067 & 59 & 0,183 & 0,057 & 31 & 13,009 \\
2008 & 33,037 & 20,116 & 61 & 0,197 & 0,074 & 38 & 20,042 \\
2009 & 34,359 & 22,754 & 66 & 0,148 & 0,076 & 51 & 22,678 \\
2010 & 30,096 & 19,419 & 65 & 0,124 & 0,077 & 62 & 19,343 \\
2011 & 40,432 & 27,330 & 68 & 0,042 & 0,027 & 65 & 27,303 \\
2012 & 51,053 & 34,114 & 67 & 0,305 & 0,298 & 98 & 33,816 \\
2013 & 66,883 & 49,272 & 74 & 0,293 & 0,275 & 94 & 48,998 \\
2014 & 73,937 & 54,797 & 74 & 0,606 & 0,602 & 99 & 54,195 \\
\hline
\end{tabular}

Nota: valores convertidos para a moeda nacional corrente, taxa de câmbio: dólar dos Estados Unidos da América, obtida através de elaboração de média para cada ano pesquisado.

Fonte: elaborado pelos autores com base em Fiergs (2016). 
Tabela 3 - Evolução da produção, volume e valor de exportação de soja em grão no Brasil de 1996 a 2014

\begin{tabular}{c|c|c|c|c}
\hline Anos & Produção (t/milhões) & Exportação (t/milhões) & R\$ bilhões ${ }^{1}$ & $\begin{array}{c}\text { Participação das } \\
\text { exportações na produção }\end{array}$ \\
\hline 1996 & 23,16 & 3,65 & 1,022 & $15,75 \%$ \\
1997 & 26,39 & 7,79 & 2,643 & $29,51 \%$ \\
1998 & 31,31 & 9,30 & 2,527 & $29,71 \%$ \\
1999 & 30,99 & 8,80 & 2,664 & $28,39 \%$ \\
2000 & 32,82 & 11,51 & 4,001 & $41,06 \%$ \\
2001 & 37,91 & 15,66 & 6,409 & $37,91 \%$ \\
2002 & 42,11 & 15,96 & 8,884 & $38,29 \%$ \\
2003 & 51,92 & 19,88 & 13,175 & $38,87 \%$ \\
2004 & 49,55 & 19,26 & 15,780 & $43,82 \%$ \\
2005 & 51,18 & 22,43 & 13,006 & $47,56 \%$ \\
2006 & 52,46 & 24,95 & 12,325 & $41,03 \%$ \\
2007 & 57,86 & 23,74 & 13,067 & $41,64 \%$ \\
2008 & 59,83 & 20,116 & $49,81 \%$ \\
2009 & 57,35 & 24,91 & 22,754 & $42,27 \%$ \\
2010 & 68,76 & 28,56 & 19,419 & $44,11 \%$ \\
2011 & 74,82 & 29,07 & 27,330 & $49,98 \%$ \\
2012 & 65,85 & 33,00 & 34,114 & $52,50 \%$ \\
2013 & 81,72 & 32,91 & 49,272 & $53,81 \%$ \\
\hline
\end{tabular}

Nota: ${ }^{1}$ informações da exportação de soja em grão a partir da cesta de produtos: soja para semeadura; outros grãos de soja mesmo triturados; soja mesmo triturada, para semeadura; soja mesmo triturada, exceto para semeadura. Valores convertidos para a moeda nacional corrente, taxa de câmbio: dólar dos Estados Unidos da América, obtida através de elaboração de média para cada ano pesquisado.

Fonte: elaborado pelos autores com base em Aliceweb (2016a); IBGE (2016); Bacen (2016).

Tabela 4 - Participação do Estado do Rio Grande do Sul na Balança Comercial Brasileira de 1996 a 2014 (R\$ Bilhões)

\begin{tabular}{c|c|c|c|c|c|c|c|c}
\hline \multirow{2}{*}{ Ano } & \multicolumn{2}{|c|}{ Exportações Totais } & \multicolumn{2}{|c|}{ Importações Totais } & \multicolumn{2}{|c|}{ Participação do RS } & $\begin{array}{c}\text { Saldo Comercial } \\
\text { RS (a-b) }\end{array}$ \\
\cline { 2 - 7 } & Brasil & RS (a) & Brasil & RS (b) & Exp. & Imp. & 2,313 \\
1996 & 47,747 & 5,689 & 53,346 & 3,376 & $12 \%$ & $6 \%$ & $7 \%$ & 2,743 \\
1997 & 52,994 & 6,755 & 59,747 & 4,013 & $13 \%$ & $7 \%$ & 1,504 \\
1998 & 51,140 & 6,529 & 57,763 & 5,025 & $13 \%$ & $9 \%$ & $11 \%$ & 2,868 \\
1999 & 48,013 & 8,357 & 49,302 & 5,489 & $17 \%$ & $19 \%$ & $13 \%$ & 3,217 \\
2000 & 55,119 & 10,576 & 55,851 & 7,358 & $26 \%$ & $17 \%$ & 5,413 \\
2001 & 58,287 & 14,936 & 55,602 & 9,524 & $31 \%$ & $22 \%$ & 8,357 \\
2002 & 60,439 & 18,705 & 47,243 & 10,348 & $34 \%$ & $27 \%$ & 11,781 \\
2003 & 73,203 & 24,650 & 48,326 & 12,869 & $34 \%$ & 13,488 \\
2004 & 96,677 & 28,963 & 62,836 & 15,475 & $30 \%$ & $25 \%$ & 9,206 \\
2005 & 118,529 & 25,491 & 73,600 & 16,284 & $22 \%$ & $22 \%$ & $19 \%$ & 8,385 \\
2006 & 137,807 & 25,685 & 91,351 & 17,300 & $19 \%$ & $18 \%$ & $16 \%$ & 9,444 \\
2007 & 160,649 & 29,247 & 120,617 & 19,803 & $17 \%$ & $15 \%$ & 7,029 \\
2008 & 197,942 & 33,706 & 172,985 & 26,678 & $17 \%$ & 11,481 \\
2009 & 152,995 & 30,346 & 127,722 & 18,864 & $20 \%$ & $15 \%$ & $13 \%$ & 3,706 \\
2010 & 201,915 & 27,050 & 181,768 & 23,344 & $13 \%$ & $13 \%$ \\
2011 & 256,040 & 32,519 & 226,247 & 26,216 & $13 \%$ & $12 \%$ & 6,303 \\
2012 & 242,578 & 33,979 & 223,183 & 30,039 & $14 \%$ & $13 \%$ & 3,940 \\
2013 & 242,034 & 54,200 & 239,748 & 36,207 & $22 \%$ & $15 \%$ & 17,993 \\
2014 & 225,101 & 43,805 & 229,154 & 35,149 & $19 \%$ & $15 \%$ & 8,656 \\
\hline
\end{tabular}

Nota: valores convertidos para a moeda nacional corrente, taxa de câmbio: dólar dos Estados Unidos da América, obtida através de elaboração de média para cada ano pesquisado.

Fonte: elaborado pelos autores com base em Fiergs (2016).

Teoria e Evidência Econômica - a. 24, n. 50, p. 51-88, jan./jun. 2018 
Tabela 5 - Participação do agronegócio na Balança Comercial do Estado do Rio Grande do Sul de 1996 a 2014 (R\$ Bilhões)

\begin{tabular}{c|c|c|c|c|c|c|c|c}
\hline \multirow{2}{*}{ Ano } & \multicolumn{3}{|c|}{ Exportações } & \multicolumn{3}{c|}{ Importações } & \multicolumn{3}{c}{ Saldo } \\
\cline { 2 - 8 } & Total (a) & Agronegócio (b) & Part. \% & Total (c) & Agronegócio (d) & Part. \% & Total (a-c) & Agronegócio (b-d) \\
\hline 1996 & 5,689 & 4,080 & 72 & 3,376 & 0,891 & 22 & 1,609 & 3,189 \\
1997 & 6,755 & 4,764 & 71 & 4,013 & 0,982 & 21 & 1,991 & 3,782 \\
1998 & 6,529 & 4,472 & 68 & 5,025 & 1,268 & 28 & 2,057 & 3,204 \\
1999 & 8,357 & 5,719 & 68 & 5,489 & 1,011 & 18 & 2,638 & 4,707 \\
2000 & 10,576 & 6,684 & 63 & 7,358 & 1,071 & 16 & 3,892 & 5,613 \\
2001 & 14,936 & 10,291 & 69 & 9,524 & 1,260 & 12 & 4,645 & 9,030 \\
2002 & 18,705 & 12,621 & 67 & 10,348 & 1,315 & 10 & 6,084 & 11,306 \\
2003 & 24,650 & 16,134 & 65 & 12,869 & 1,815 & 11 & 8,516 & 14,319 \\
2004 & 28,963 & 18,182 & 63 & 15,475 & 1,475 & 8 & 10,781 & 16,707 \\
2005 & 25,491 & 14,435 & 57 & 16,284 & 1,216 & 8 & 11,055 & 13,219 \\
2006 & 25,685 & 15,133 & 59 & 17,300 & 1,220 & 8 & 10,552 & 13,913 \\
2007 & 29,247 & 17,192 & 59 & 19,803 & 1,340 & 8 & 12,055 & 15,851 \\
2008 & 33,706 & 19,386 & 58 & 26,678 & 1,654 & 9 & 14,320 & 17,733 \\
2009 & 30,346 & 18,005 & 59 & 18,864 & 1,356 & 8 & 12,340 & 16,649 \\
2010 & 27,050 & 16,366 & 61 & 23,344 & 1,524 & 9 & 10,684 & 14,841 \\
2011 & 32,519 & 20,096 & 62 & 26,216 & 1,504 & 7 & 12,423 & 18,592 \\
2012 & 33,979 & 20,808 & 61 & 30,039 & 1,826 & 9 & 13,170 & 18,982 \\
2013 & 54,200 & 27,953 & 52 & 36,207 & 2,178 & 8 & 26,247 & 25,775 \\
2014 & 43,805 & 28,273 & 65 & 35,149 & 2,070 & 7 & 15,531 & 26,204 \\
\hline
\end{tabular}

Nota: valores convertidos para a moeda nacional corrente, taxa de câmbio: dólar dos Estados Unidos da América, obtida através de elaboração de média para cada ano pesquisado.

Fonte: elaborado pelos autores com base em Fiergs (2016).

Tabela 6 - Participação da soja em grão na Balança Comercial do Agronegócio no Rio Grande do Sul de 1996 a 2014 (R\$ Bilhões)

\begin{tabular}{c|c|c|c|c|c|c|c}
\hline \multirow{2}{*}{ Ano } & \multicolumn{3}{|c|}{ Exportações } & \multicolumn{3}{|c|}{ Importações } & Saldo Comercial \\
\cline { 2 - 7 } & Agronegócio & Soja Grão (a) & Part. \% & Agronegócio & Soja Grão (b) & Part. \% & Soja Grão (a-b) \\
\hline 1996 & 4,080 & 0,040 & 1 & 0,891 & 0,032 & 4 & 0,008 \\
1997 & 4,764 & 0,338 & 7 & 0,982 & 0,042 & 4 & 0,296 \\
1998 & 4,472 & 0,340 & 8 & 1,268 & 0,057 & 5 & 0,283 \\
1999 & 5,719 & 0,175 & 3 & 1,011 & 0,000 & 0 & 0,175 \\
2000 & 6,684 & 0,486 & 7 & 1,071 & 0,000 & 0 & 0,486 \\
2001 & 10,291 & 1,139 & 11 & 1,260 & 0,000 & 0 & 1,139 \\
2002 & 12,621 & 1,021 & 8 & 1,315 & 0,000 & 0 & 1,021 \\
2003 & 16,134 & 2,580 & 16 & 1,815 & 0,001 & 0 & 2,579 \\
2004 & 18,182 & 1,848 & 10 & 1,475 & 0,000 & 0 & 1,848 \\
2005 & 14,435 & 0,262 & 2 & 1,216 & 0,003 & 0 & 0,259 \\
2006 & 15,133 & 1,609 & 11 & 1,220 & 0,000 & 0 & 1,608 \\
2007 & 17,192 & 3,128 & 18 & 1,340 & 0,000 & 0 & 3,128 \\
2008 & 19,386 & 2,972 & 15 & 1,654 & 0,000 & 0 & 2,972 \\
2009 & 18,005 & 3,857 & 21 & 1,356 & 0,008 & 1 & 3,850 \\
2010 & 16,366 & 3,134 & 19 & 1,524 & 0,027 & 2 & 3,108 \\
2011 & 20,096 & 4,957 & 25 & 1,504 & 0,000 & 0 & 4,957 \\
2012 & 20,808 & 3,861 & 19 & 1,826 & 0,125 & 7 & 3,736 \\
2013 & 27,953 & 9,128 & 33 & 2,178 & 0,068 & 3 & 9,060 \\
2014 & 28,273 & 9,385 & 33 & 2,070 & 0,105 & 5 & 9,280 \\
\hline
\end{tabular}

Nota: valores convertidos para a moeda nacional corrente, taxa de câmbio: dólar dos Estados Unidos da América, obtida através de elaboração de média para cada ano pesquisado.

Fonte: elaborado pelos autores com base em Fiergs (2016). 
Tabela 7 - Participação do Estado do Rio Grande do Sul na produção brasileira de soja: 1996 a 2014

\begin{tabular}{c|c|c|c}
\hline Anos & Brasil (t) & RS(t) & Participação Relativa do RS no Brasil \\
\hline 1996 & 23,16 & 4,24 & $18,29 \%$ \\
1997 & 26,39 & 4,76 & $18,02 \%$ \\
1998 & 31,31 & 6,46 & $20,64 \%$ \\
1999 & 30,99 & 4,47 & $14,42 \%$ \\
2000 & 32,82 & 4,78 & $14,58 \%$ \\
2001 & 37,91 & 6,95 & $18,34 \%$ \\
2002 & 42,11 & 5,61 & $13,32 \%$ \\
2003 & 51,92 & 9,58 & $18,45 \%$ \\
2004 & 49,55 & 5,54 & $11,18 \%$ \\
2005 & 51,18 & 2,44 & $4,78 \%$ \\
2006 & 52,46 & 7,56 & $14,41 \%$ \\
2007 & 57,86 & 9,93 & $17,16 \%$ \\
2008 & 59,83 & 7,68 & $12,84 \%$ \\
2009 & 57,35 & 8,03 & $13,99 \%$ \\
2010 & 68,76 & 10,48 & $15,24 \%$ \\
2011 & 74,82 & 11,72 & $15,66 \%$ \\
2012 & 65,85 & 5,95 & $9,03 \%$ \\
2013 & 81,72 & 12,76 & $15,61 \%$ \\
2014 & 86,76 & 13,04 & $15,03 \%$ \\
\hline
\end{tabular}

Fonte: elaborado pelos autores com base em IBGE (2016).

Tabela 8 - Participação relativa do Estado do Rio Grande do Sul nas exportações nacionais de soja em grão ${ }^{1}$ de 1996 a 2014

\begin{tabular}{c|c|c|c}
\hline Anos & Quantidade exportada no Brasil (t) & Quantidade exportada no RS (t) & Participação \\
\hline 1996 & 3.646 .938 & 141.933 & $3,89 \%$ \\
1997 & 7.787 .662 & 1.003 .239 & $12,88 \%$ \\
1998 & 9.300 .513 & 1.266 .184 & $13,61 \%$ \\
1999 & 8.798 .745 & 595.856 & $6,77 \%$ \\
2000 & 11.506 .884 & 1.400 .859 & $12,17 \%$ \\
2001 & 15.655 .886 & 2.837 .486 & $18,12 \%$ \\
2002 & 15.962 .466 & 1.794 .444 & $11,24 \%$ \\
2003 & 19.881 .279 & 3.790 .086 & $19,06 \%$ \\
2004 & 19.258 .372 & 2.198 .251 & $11,41 \%$ \\
2005 & 22.429 .220 & 439.229 & $1,96 \%$ \\
2006 & 24.949 .617 & 3.278 .282 & $13,14 \%$ \\
2007 & 23.740 .450 & 5.500 .862 & $23,17 \%$ \\
2008 & 24.912 .341 & 3.515 .963 & $14,11 \%$ \\
2009 & 28.561 .691 & 4.853 .788 & $16,99 \%$ \\
2010 & 29.065 .224 & 4.683 .882 & $16,12 \%$ \\
2011 & 33.001 .379 & 5.866 .515 & $17,78 \%$ \\
2012 & 32.909 .895 & 3.586 .545 & $10,90 \%$ \\
2013 & 42.904 .658 & 7.872 .785 & $18,35 \%$ \\
2014 & 46.688 .588 & 7.698 .483 & $16,49 \%$ \\
\hline
\end{tabular}

Nota: ${ }^{1}$ informações da exportação de soja em grão a partir da cesta de produtos: soja para semeadura; outros grãos de soja mesmo triturados; soja mesmo triturada, para semeadura; soja mesmo triturada, exceto para semeadura.

Fonte: elaborado pelos autores com base em Aliceweb (2016b).

Teoria e Evidência Econômica - a. 24, n. 50, p. 51-88, jan./jun. 2018 
Tabela 9 - Balança Comercial Total e da Soja no COREDE Produção de 1997 a 2014 (R\$ Milhões)

\begin{tabular}{|c|c|c|c|c|c|c|}
\hline \multirow{2}{*}{ Ano } & \multicolumn{2}{|c|}{ Exportações } & \multicolumn{2}{|c|}{ Importações } & \multicolumn{2}{|c|}{ Saldos } \\
\hline & Totais (a) & Soja Grão (b) & Totais (c) & Soja Grão (d) & Totais $(a-c)$ & Soja Grão (b-d) \\
\hline 1997 & 138,907 & 12,568 & 24,818 & 0,000 & 114,089 & 12,568 \\
\hline 1998 & 106,240 & 3,528 & 42,110 & 0,000 & 64,129 & 3,528 \\
\hline 1999 & 137,954 & 14,390 & 37,473 & 0,000 & 100,481 & 14,390 \\
\hline 2000 & 131,202 & 13,881 & 42,570 & 0,000 & 88,632 & 13,881 \\
\hline 2001 & 263,808 & 21,415 & 57,287 & 0,000 & 206,521 & 21,415 \\
\hline 2002 & 326,530 & 32,591 & 53,334 & 0,000 & 273,197 & 32,591 \\
\hline 2003 & 246,669 & 118,627 & 36,673 & 0,000 & 209,996 & 118,627 \\
\hline 2004 & 253,241 & 93,122 & 49,238 & 0,000 & 204,003 & 93,122 \\
\hline 2005 & 124,896 & 10,946 & 41,875 & 0,000 & 83,022 & 10,946 \\
\hline 2006 & 98,029 & 17,375 & 34,327 & 0,000 & 63,702 & 17,375 \\
\hline 2007 & 135,320 & 11,621 & 53,050 & 0,000 & 82,270 & 11,621 \\
\hline 2008 & 257,952 & 18,080 & 175,882 & 0,000 & 82,069 & 18,080 \\
\hline 2009 & 218,752 & 79,604 & 85,107 & 0,000 & 133,645 & 79,604 \\
\hline 2010 & 402,568 & 95,496 & 74,508 & 0,000 & 328,060 & 95,496 \\
\hline 2011 & $1.226,587$ & 404,512 & 129,449 & 0,001 & $1.097,138$ & 404,511 \\
\hline 2012 & $1.221,004$ & 336,504 & 247,425 & 5,789 & 973,578 & 330,715 \\
\hline 2013 & $2.299,652$ & 983,301 & 317,976 & 22,642 & $1.981,676$ & 960,658 \\
\hline 2014 & $2.153,069$ & $1.068,325$ & 284,081 & 1,024 & $1.868,988$ & $1.067,301$ \\
\hline
\end{tabular}

Nota: ${ }^{1}$ informações da exportação e importação de soja em grão a partir da cesta de produtos: soja para semeadura; outros grãos de soja mesmo triturados; soja mesmo triturada, para semeadura; soja mesmo triturada, exceto para semeadura. Valores convertidos para a moeda nacional corrente, taxa de câmbio: dólar dos Estados Unidos da América, obtida através de elaboração de média para cada ano pesquisado.

Fonte: elaborado pelos autores com base em Aliceweb (2016b).

Tabela 10 - Evolução e participação do COREDE Produção na área plantada de soja no Rio Grande do Sul: 1997-2014

\begin{tabular}{c|c|c|c}
\hline Anos & Área Plantada RS (ha) & Área Plantada COREDE (ha) & Participação COREDE \\
\hline 1997 & 2.942 .882 & 239.230 & $8 \%$ \\
1998 & 3.176 .290 & 250.335 & $8 \%$ \\
1999 & 3.054 .603 & 251.470 & $8 \%$ \\
2000 & 3.030 .556 & 231.530 & $8 \%$ \\
2001 & 2.976 .498 & 224.316 & $7 \%$ \\
2002 & 3.307 .252 & 246.730 & $7 \%$ \\
2003 & 3.591 .970 & 256.600 & $7 \%$ \\
2004 & 3.984 .337 & 272.100 & $7 \%$ \\
2005 & 4.179 .272 & 283.655 & $7 \%$ \\
2006 & 3.868 .501 & 266.550 & $7 \%$ \\
2007 & 3.890 .903 & 276.950 & $7 \%$ \\
2008 & 3.804 .425 & 249.650 & $7 \%$ \\
2009 & 3.823 .246 & 275.450 & $7 \%$ \\
2010 & 4.021 .778 & 292.250 & $7 \%$ \\
2011 & 4.075 .389 & 294.450 & $7 \%$ \\
2012 & 4.269 .247 & 290.450 & $7 \%$ \\
2013 & 4.727 .833 & 304.600 & $6 \%$ \\
2014 & 4.990 .042 & 311.350 & $7 \%$ \\
\hline
\end{tabular}

Fonte: elaborado pela autora com base em IBGE (2016). 
Tabela 11 - Produtividade de soja no Corede Produção e demais regiões do RS de 1997 a 2014

\begin{tabular}{c|c|c|c|c|c|c}
\hline \multirow{2}{*}{ Anos } & \multicolumn{3}{|c|}{ Demais regiões do RS ${ }^{(1)}$} & \multicolumn{3}{c}{ COREDE Produção } \\
\cline { 2 - 7 } & $\begin{array}{c}\text { Área Plantada } \\
\text { (ha) }\end{array}$ & Produção (t) & Produtividade (t/ha) & Área Plantada (ha) & Produção (t) & $\begin{array}{c}\text { Produtividade } \\
\text { (t/ha) }\end{array}$ \\
\hline 1997 & 2.703 .652 & 4.344 .062 & 1,61 & 239.230 & 410.938 & 1,72 \\
1998 & 2.925 .955 & 5.881 .940 & 2,01 & 250.335 & 580.575 & 2,32 \\
1999 & 2.803 .133 & 4.061 .013 & 1,45 & 251.470 & 406.097 & 1,61 \\
2000 & 2.799 .026 & 4.303 .474 & 1,54 & 231.530 & 480.421 & 2,07 \\
2001 & 2.752 .182 & 6.364 .559 & 2,31 & 224.316 & 587.271 & 2,62 \\
2002 & 3.060 .522 & 5.067 .393 & 1,66 & 246.730 & 543.125 & 2,20 \\
2003 & 3.335 .370 & 8.819 .353 & 2,64 & 256.600 & 759.944 & 2,96 \\
2004 & 3.712 .237 & 5.010 .427 & 1,35 & 272.100 & 531.287 & 1,95 \\
2005 & 3.895 .617 & 2.281 .768 & 0,59 & 283.655 & 162.772 & 0,57 \\
2006 & 3.601 .951 & 6.891 .691 & 1,91 & 266.550 & 667.600 & 2,50 \\
2007 & 3.613 .953 & 9.130 .064 & 2,53 & 246.950 & 798.941 & 2,88 \\
2008 & 3.554 .775 & 7.101 .115 & 2,00 & 275.650 & 578.824 & 2,32 \\
2009 & 3.547 .796 & 7.419 .458 & 2,09 & 292.250 & 8405.864 & 2,20 \\
2010 & 3.729 .528 & 9.631 .566 & 2,58 & 294.450 & 940.896 & 2,90 \\
2011 & 3.780 .939 & 10.776 .652 & 2,85 & 290.450 & 621.675 & 3,20 \\
2012 & 3.978 .797 & 5.323 .568 & 1,34 & 304.600 & 933.705 & 2,14 \\
2013 & 4.423 .233 & 11.822 .872 & 2,67 & 311.350 & 863.585 & 3,07 \\
2014 & 4.678 .692 & 12.178 .135 & 2,60 & & 2,77 \\
\hline
\end{tabular}

Fonte: elaborado pelos autores com base em IBGE (2016).

Tabela 12 - Evolução e participação do COREDE na produção de soja no Rio Grande do Sul: 1996-2014

\begin{tabular}{c|c|cc}
\hline Ano & Produção RS(t) & Produção COREDE (t) & Participação COREDE \\
\hline 1997 & 4.755 .000 & 410.938 & $9 \%$ \\
1998 & 6.462 .515 & 580.575 & $9 \%$ \\
1999 & 4.467 .110 & 406.097 & $10 \%$ \\
2000 & 4.783 .895 & 480.421 & $8 \%$ \\
2001 & 6.951 .830 & 587.271 & $10 \%$ \\
2002 & 5.610 .518 & 543.125 & $8 \%$ \\
2003 & 9.579 .297 & 759.944 & $10 \%$ \\
2004 & 5.541 .714 & 531.287 & $7 \%$ \\
2005 & 2.444 .540 & 162.772 & $9 \%$ \\
2006 & 7.559 .291 & 667.600 & $8 \%$ \\
2007 & 9.929 .005 & 798.941 & $8 \%$ \\
2008 & 7.679 .939 & 578.824 & $8 \%$ \\
2009 & 8.025 .322 & 605.864 & $8 \%$ \\
2010 & 10.480 .026 & 848.460 & $8 \%$ \\
2011 & 11.717 .548 & 940.896 & $10 \%$ \\
2012 & 5.945 .243 & 621.675 & $7 \%$ \\
2013 & 12.756 .577 & 933.705 & $8 \%$ \\
2014 & 13.041 .720 & 863.585 & $8 \%$ \\
\hline Total Acumulado & 137.731 .090 & 11.321 .980 & 865.999 \\
Média por ano & 8.101 .829 & & $8 \%$ \\
\hline
\end{tabular}

Fonte: elaborado pelos autores com base em IBGE (2016).

Teoria e Evidência Econômica - a. 24, n. 50, p. 51-88, jan./jun. 2018 
Tabela 13 - Evolução e participação das exportações na produção de soja no COREDE Produção de 1997 a 2014

\begin{tabular}{|c|c|c|c|c|}
\hline Anos & Produção (t) & Exportação $(t)^{1}$ & Exportação (R\$) & $\begin{array}{c}\text { Participação das } \\
\text { exportações na produção }\end{array}$ \\
\hline $\begin{array}{l}1997 \\
1998\end{array}$ & $\begin{array}{l}410.938 \\
580.575\end{array}$ & $\begin{array}{l}38.900 \\
13.000\end{array}$ & $\begin{array}{r}12.559 .717,89 \\
3.528 .024,00\end{array}$ & $\begin{array}{l}9 \% \\
2 \%\end{array}$ \\
\hline 1999 & 406.097 & 35.909 & $14.389 .964,07$ & $9 \%$ \\
\hline 2000 & 480.421 & 34.912 & $13.881 .254,71$ & $7 \%$ \\
\hline 2001 & 587.271 & 42.216 & $21.414 .756,12$ & $7 \%$ \\
\hline 2002 & 543.125 & 55.829 & $32.591 .355,80$ & $10 \%$ \\
\hline 2003 & 759.944 & 173.939 & $118.626 .760,38$ & $23 \%$ \\
\hline 2004 & 531.287 & 113.660 & $93.121 .857,66$ & $21 \%$ \\
\hline 2005 & 162.772 & 19.063 & $10.946 .141,65$ & $12 \%$ \\
\hline 2006 & 667.600 & 36.000 & $17.375 .035,13$ & $5 \%$ \\
\hline 2007 & 798.941 & 21.500 & $11.621 .238,85$ & $3 \%$ \\
\hline 2008 & 578.824 & 25.500 & $18.079 .795,22$ & $4 \%$ \\
\hline 2009 & 605.864 & 87.328 & $79.603 .618,30$ & $14 \%$ \\
\hline 2010 & 848.460 & 143.987 & $95.495 .954,46$ & $17 \%$ \\
\hline 2011 & 940.896 & 464.149 & $404.512 .208,35$ & $49 \%$ \\
\hline 2012 & 621.675 & 340.274 & $336.504 .253,23$ & $55 \%$ \\
\hline 2013 & 933.705 & 858.610 & $983.300 .686,87$ & $92 \%$ \\
\hline 2014 & 863.585 & 856.678 & $1.068 .325 .159,37$ & $99 \%$ \\
\hline
\end{tabular}

Nota: ${ }^{1}$ informações da exportação de soja em grão a partir da cesta de produtos: soja para semeadura; outros grãos de soja mesmo triturados; soja mesmo triturada, para semeadura; soja mesmo triturada, exceto para semeadura. Valores convertidos para a moeda nacional corrente, taxa de câmbio: dólar dos Estados Unidos da América, obtida através de elaboração de média para cada ano pesquisado.

Fonte: elaborado pelos autores com base em Aliceweb (2016b); IBGE (2016).

Tabela 14 - Participação das exportações na produção de soja nos municípios exportadores (Carazinho, Casca, Marau e Passo Fundo) de 1997 a 2014

\begin{tabular}{c|c|c|c}
\hline Ano & Produção $(\mathrm{t})$ & Exportação $(\mathrm{t})^{1}$ & $\begin{array}{c}\text { Participação das exportações na } \\
\text { produção }\end{array}$ \\
\hline 1997 & 190.400 & 38.900 & $20 \%$ \\
1998 & 269.620 & 13.000 & $19 \%$ \\
1999 & 185.184 & 35.909 & $15 \%$ \\
2000 & 230.570 & 34.912 & $17 \%$ \\
2001 & 246.660 & 42.216 & $24 \%$ \\
2002 & 230.110 & 55.829 & $55 \%$ \\
2003 & 314.700 & 173.939 & $51 \%$ \\
2004 & 223.140 & 113.660 & $31 \%$ \\
2005 & 61.392 & 19.063 & $14 \%$ \\
2006 & 258.136 & 36.000 & $7 \%$ \\
2007 & 322.776 & 21.500 & $10 \%$ \\
2008 & 252.386 & 25.500 & $34 \%$ \\
2009 & 253.994 & 87.328 & $45 \%$ \\
2010 & 319.710 & 143.987 & $128 \%$ \\
2011 & 363.770 & 464.149 & $156 \%$ \\
2012 & 218.220 & 340.274 & $233 \%$ \\
2013 & 367.800 & 858.610 & $257 \%$ \\
\hline
\end{tabular}

Nota: ${ }^{1}$ Informações da exportação de soja em grão a partir da cesta de produtos: soja para semeadura; outros grãos de soja mesmo triturados; soja mesmo triturada, para semeadura; soja mesmo triturada, exceto para semeadura.

Fonte: elaborado pelos autores com base em Aliceweb (2016b); IBGE (2016).

Teoria e Evidência Econômica - a. 24, n. 50, p. 51-88, jan./jun. 2018 
Tabela 15 - Balança Comercial Brasileira e Balança Comercial do Agronegócio: 1989 a 2015

\begin{tabular}{|c|c|c|c|c|c|c|c|c|}
\hline \multicolumn{9}{|c|}{ US\$ Bilhões } \\
\hline \multirow[b]{2}{*}{ Ano } & \multicolumn{3}{|c|}{ Exportações } & \multicolumn{3}{|c|}{ Importações } & \multicolumn{2}{|c|}{ Saldo } \\
\hline & $\begin{array}{l}\text { Total Brasil } \\
\text { (A) }\end{array}$ & $\begin{array}{l}\text { Agronegócio } \\
\text { (B) }\end{array}$ & $\begin{array}{l}\text { Part. \% } \\
\text { (B/A) }\end{array}$ & $\begin{array}{l}\text { Total Brasil } \\
\text { (C) }\end{array}$ & $\begin{array}{l}\text { Agronegócio } \\
\text { (D) }\end{array}$ & $\begin{array}{l}\text { Part.\% } \\
\text { (D/C) }\end{array}$ & Total Brasil & Agronegócio \\
\hline 1989 & 34,383 & 13,921 & 40,49 & 18,263 & 3,081 & 16,87 & 16,119 & 10,840 \\
\hline 1990 & 31,414 & 12,990 & 41,35 & 20,661 & 3,184 & 15,41 & 10,752 & 9,806 \\
\hline 1991 & 31,620 & 12,403 & 39,23 & 21,040 & 3,642 & 17,31 & 10,580 & 8,761 \\
\hline 1992 & 35,793 & 14,455 & 40,38 & 20,554 & 2,962 & 14,41 & 15,239 & 11,492 \\
\hline 1993 & 38,555 & 15,940 & 41,34 & 25,256 & 4,157 & 16,46 & 13,299 & 11,783 \\
\hline 1994 & 43,545 & 19,105 & 43,87 & 33,079 & 5,678 & 17,16 & 10,466 & 13,427 \\
\hline 1995 & 46,506 & 20,871 & 44,88 & 49,972 & 8,613 & 17,24 & $-3,466$ & 12,258 \\
\hline 1996 & 47,747 & 21,145 & 44,29 & 53,346 & 8,939 & 16,76 & $-5,599$ & 12,206 \\
\hline 1997 & 52,994 & 23,376 & 44,11 & 59,747 & 8,197 & 13,72 & $-6,753$ & 15,178 \\
\hline 1998 & 51,140 & 21,555 & 42,15 & 57,763 & 8,045 & 13,93 & $-6,624$ & 13,511 \\
\hline 1999 & 48,013 & 20,501 & 42,70 & 49,302 & 5,697 & 11,56 & $-1,289$ & 14,804 \\
\hline 2000 & 55,119 & 20,605 & 37,38 & 55,851 & 5,759 & 10,31 & $-0,732$ & 14,845 \\
\hline 2001 & 58,287 & 23,866 & 40,95 & 55,602 & 4,805 & 8,64 & 2,685 & 19,061 \\
\hline 2002 & 60,439 & 24,846 & 41,11 & 47,243 & 4,452 & 9,42 & 13,196 & 20,394 \\
\hline 2003 & 73,203 & 30,653 & 41,87 & 48,326 & 4,750 & 9,83 & 24,878 & 25,903 \\
\hline 2004 & 96,677 & 39,035 & 40,38 & 62,836 & 4,836 & 7,70 & 33,842 & 34,200 \\
\hline 2005 & 118,529 & 43,623 & 36,80 & 73,600 & 5,112 & 6,95 & 44,929 & 38,511 \\
\hline 2006 & 137,807 & 49,471 & 35,90 & 91,351 & 6,699 & 7,33 & 46,457 & 42,772 \\
\hline 2007 & 160,649 & 58,431 & 36,37 & 120,617 & 8,732 & 7,24 & 40,032 & 49,699 \\
\hline 2008 & 197,942 & 71,837 & 36,29 & 172,985 & 11,881 & 6,87 & 24,958 & 59,957 \\
\hline 2009 & 152,995 & 64,786 & 42,34 & 127,722 & 9,900 & 7,75 & 25,272 & 54,885 \\
\hline 2010 & 201,915 & 76,442 & 37,86 & 181,768 & 13,399 & 7,37 & 20,147 & 63,043 \\
\hline 2011 & 256,040 & 94,968 & 37,09 & 226,247 & 17,508 & 7,74 & 29,793 & 77,460 \\
\hline 2012 & 242,578 & 95,814 & 39,50 & 223,183 & 16,409 & 7,35 & 19,395 & 79,405 \\
\hline 2013 & 242,034 & 99,968 & 41,30 & 239,748 & 17,061 & 7,12 & 2,286 & 82,907 \\
\hline 2014 & 225,101 & 96,748 & 42,98 & 229,154 & 16,614 & 7,25 & $-4,054$ & 80,134 \\
\hline 2015 & 191,134 & 88,224 & 46,16 & 171,449 & 13,073 & 7,63 & 19,685 & 75,151 \\
\hline
\end{tabular}

Fonte: Agrostat Brasil a partir de dados da SECEX/MDIC.

Elaboração: DAC / SRI / MAPA. 